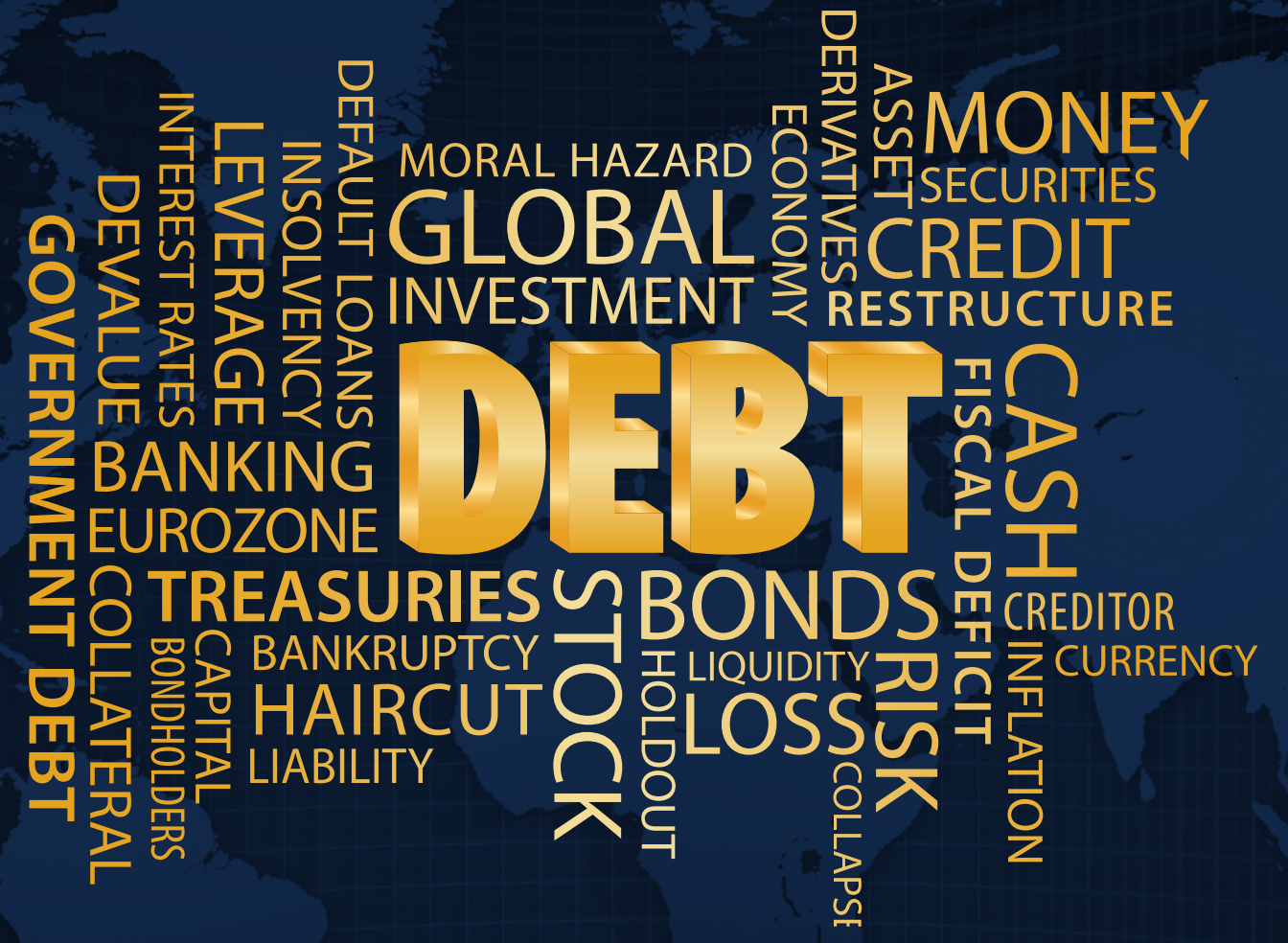

\title{
REVISITING SOVEREIGN BANKRUPTCY
}

\section{Committee on International Economic Policy and Reform}

LEAD AUTHORS

Lee C. Buchheit

Anna Gelpern

Mitu Gulati

$$
\text { Ugo Panizza }
$$

Beatrice Weder di Mauro

Jeromin Zettelmeyer

OTHER COMMITTEE MEMBERS

Markus Brunnermeier

Barry Eichengreen

Mohamed El-Erian

José De Gregorio
Takatoshi Ito

Philip Lane

Eswar Prasad

Hélène Rey
Dani Rodrik

Hyun Song Shin

Andrés Velasco

Yongding Yu 


\section{TABLE OF CONTENTS}

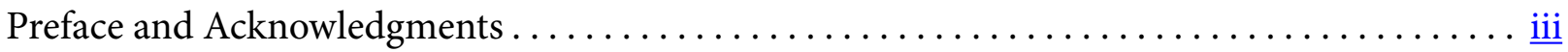

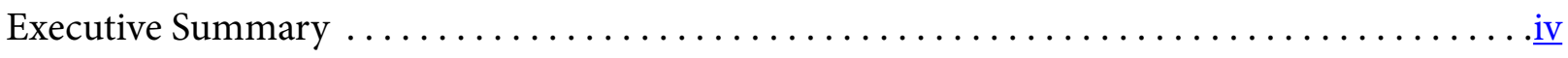

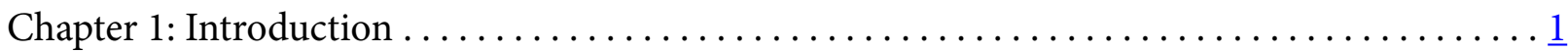

Chapter 2: Pathologies in Sovereign Debt $\ldots \ldots \ldots \ldots \ldots \ldots \ldots \ldots \ldots \ldots \ldots \ldots \ldots \ldots \ldots \ldots \ldots \ldots \ldots \ldots \ldots \ldots$

Chapter 3: Argentina and the Rebirth of the Holdout Problem $\ldots \ldots \ldots \ldots \ldots \ldots \ldots \ldots \ldots$

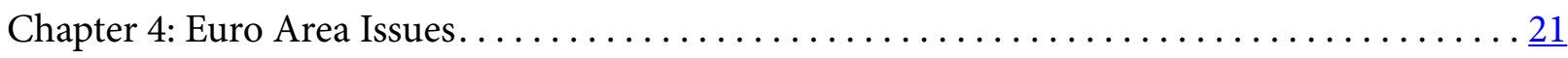

Chapter 5: Policy Proposals for the Euro Area and Beyond $\ldots \ldots \ldots \ldots \ldots \ldots \ldots \ldots \ldots$

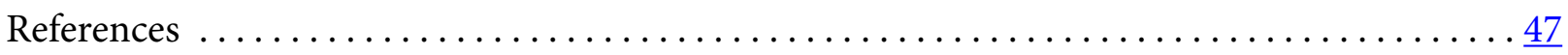




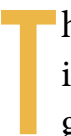

he Committee on International Economic Policy and Reform is a non-partisan, independent group of experts, comprised of academics and former government and central bank officials. Its objective is to analyze global monetary and financial problems, offer systematic analysis, and advance reform ideas. The Committee attempts to identify areas in which the global economic architecture should be strengthened and recommend solutions intended to reconcile national interests with broader global interests. Through its reports, it seeks to foster public understanding of key issues in global economic management and economic governance. Each Committee report will focus on a specific topic which will emphasize longer-term rather than conjunctural policy issues.

The Committee is grateful to the Alfred P. Sloan Foundation* for providing financial support and to the Brookings Institution for hosting the committee and facilitating its work.

Contributions by Elizabeth Broomfield and comments and suggestions by Richard Portes are gratefully acknowledged. Quynh Tonnu provided excellent administrative support.

\section{Committee Members}

Markus Brunnermeier, Princeton University

Lee C. Buchheit, Cleary Gottlieb Steen \& Hamilton $L L P$

Barry Eichengreen, University of California, Berkeley

Mohamed El-Erian, PIMCO

Anna Gelpern, Georgetown University

Mitu Gulati, Duke University

José De Gregorio, University of Chile

Takatoshi Ito, University of Tokyo

Philip Lane, Trinity College Dublin

Ugo Panizza, Graduate Institute of International and Development Studies, Geneva

Eswar Prasad, Cornell University and Brookings Institution

Hélène Rey, London Business School

Dani Rodrik, Harvard University

Hyun Song Shin, Princeton University

Andrés Velasco, Columbia University

Beatrice Weder di Mauro, University of Mainz

Yongding Yu, Chinese Academy of Social Sciences Jeromin Zettelmeyer, European Bank for

Reconstruction and Development**

**Due to his official position at EBRD, Mr. Zettelmeyer is an honorary advisor to the Committee.

${ }^{*}$ Brookings recognizes that the value it provides to any donor is in its absolute commitment to quality, independence and impact. Activities sponsored by its donors do not reflect this commitment and the research agenda, content, nor outcomes are influenced by any donation. 
overeign debt crises occur regularly and often violently. The recent debt crisis in Greece almost led to the collapse of the Euro. Yet there is no legally and politically recognized procedure for restructuring the debt of bankrupt sovereigns. Procedures of this type have been periodically debated-most recently, about a decade ago, when IMF management proposed a global sovereign debt restructuring mechanism (SDRM). They have so far been rejected. Countries have been reluctant to give up power to supranational rules or institutions. Creditors and debtors have felt that there were sufficient instruments for addressing debt crises at hoc. Importantly, there were also fears that making debt easier to restructure would raise the costs and reduce the amounts of sovereign borrowing in many countries. This was perceived to be against the interests of both the providers of both creditors and major borrowers.

This year's CIEPR report argues that both the nature and our understanding of sovereign debt problems have changed in ways that create a much stronger case for an orderly sovereign bankruptcy regime today than ten years ago.

- Pre-crisis policy mistakes-and in particular, the tendency of domestic policymakers to overborrow or pay too little attention to private debt accumulation that might turn public - are now recognized to be a much more severe problem for borrowing countries than the costs or limited availability of private financing. Far from being a problem, proposals that would limit the ability to borrow for countries with poor policies are a good thing.

- Recent court rulings-particularly a recent U.S. ruling that gives "holdout creditors" that decline a restructuring offer the right to interfere with payments to the creditors that accept such an offer. This will complicate efforts to resolve future debt crises on an ad hoc basis.

- Sovereign debt crises are no longer just a problem in emerging markets, but a core concern in advanced countries as wellparticularly in the Euro area. If the Euro is to survive, this will require both better ways to resolve debt crises and stronger, market-based incentives that prevent debt problems from occurring in the first place.

To address these problems, the report presents policy proposals at two levels: for the Euro area, and globally.

The Euro area differs from other integrated regions both in that its members have fewer instruments to deal with debt crises-they cannot devalue or inflate-and because a crisis in one member can have catastrophic consequences for others (by threatening the common currency). This requires both a mechanism for the orderly resolution of debt crises and stronger incentives to prevent them. The current financial architecture in the Euro area is inadequate in this respect, because its main pillar-the European Stability Mechanism (ESM) - is not set up to deal with unsustainable debt. If it is used even when there are significant concerns about the ability of borrowers to repay their debts, it will become source of transfers, rather than just crisis lending.

These problems could be addressed via an amendment of the ESM treaty that encourages and legitimizes - both legally and politically_debt restructuring in unsustainable debt cases. 
- First, assets and revenues of countries undertaking a debt restructuring would be deemed immune from legal action by holdouts if a restructuring is approved by the ESM.

- Second, the treaty would require a debt restructuring as a condition for ESM lending when national debts exceed a pre-set level. This should be higher than the Maastricht limit of 60 percent of GDP, but not so high as to render the constraint meaningless. In the Euro area, this may mean a level about $1 \frac{1 / 2}{2}$ times the Maastricht limit. The presence of such a debt threshold would help differentiate borrowing costs in normal times based on the strength of economic policies. At the same time, it would protect ESM resources and Euro area taxpayers, and prevent extreme adjustments of public finances at the expense of citizens who usually have little control over policy mistakes leading to excessive sovereign debt.

Importantly, Euro area countries must be given a chance to deal with legacy debt before this regime is introduced. For countries significantly above the future upper debt threshold, this will require a judgment of whether debt can be reduced below the limit within a reasonable time frame. Where the answer is no, the Euro area needs to make a choice between an upfront restructuring - backed by the ESM - and extra support, for example, in the form of providing a joint and several guarantee on new debt issuance as long as countries adhere to an agreed fiscal consolidation path.

At the global level, the relatively small size of the IMF, its de facto priority and its track record in getting repaid make it less likely that crisis lending will turn into transfers. However, experience shows that incentives are stacked against the timely recognition and restructuring of unsustainable debts. Recent court rulings encouraging holdouts, discouraging creditor participation in debt exchange offers, and bringing into question the IMF's priority status, will make this problem worse. To address this without allowing sovereigns to frivolously repudiate their debts, two alternative mechanisms are proposed.

- A coordinated introduction of a strong form of "collective action clauses" in sovereign bond contract, namely, provisions that allow for the restructuring of bonded debt with the agreement of a supermajority of creditors across all bonds.

- The creation of a Sovereign Debt Adjustment Facility by the International Monetary Fund, which would combine IMF lending with debt restructuring. A set of clearly defined ex ante criteria, analogous to those used in the HIPC initiative, would need to be developed to steer high debt countries towards this facility. An amendment of the IMF articles would ensure that the assets of countries using this facility would be shielded from holdouts if a supermajority of creditors agrees to a restructuring.

The main difference between the two proposals is that the second would do more to correct biases that delay necessary debt restructuring. Furthermore, while both would deal with the holdout problem in the long run, the IMF-based proposal would have immediate effects, while better collective action clauses would become effective only gradually, as existing debt is replaced by newly issued debt.

The world is currently less equipped to handle problems of unsustainable debt than at any time since the 1930s. At the same time, the extent of these problems has grown. Reform proposals that could address them have become more mature and more targeted, and arguments that led to the rejection of analogous proposals 10 years ago no longer apply. It is time for policy makers to tackle the central problems head on. 
overeign debt crises tend to trigger calls for sovereign bankruptcy. In the postwar era, a first round of such calls coincided with the great Latin American debt crisis of the 1980s. A second round accompanied the post-Brady debt crises, beginning with the 1995 Mexican crisis and particularly Russia's 1998 default, and leading to the International Monetary Fund's 2001 proposal for a Sovereign Debt Restructuring Mechanism (SDRM), which was intensely debated and finally rejected by IMF shareholders in April 2003. ${ }^{1}$ Since 2010, calls for some form of international sovereign bankruptcy regime have returned. ${ }^{2}$ These have been motivated partly by events in Europe, but also by difficulties in restructuring stubbornly high debt levels in other parts of the world, such as the Caribbean Sea Basin, and by ongoing litigation that could make such restructurings even harder.

This report revisits the case for a sovereign bankruptcy regime, understood as a mix of national and international institutions that would, in some conditions, sanction a comprehensive modification of sovereign debt contracts, and extend legal protections to the sovereigns and creditors involved. It formulates the economic trade-offs involved with creating such a regime, explains why and under what conditions the regime could improve welfare, and presents options for implementing the regime. Its main conclusion is that the intellectual case for-and feasibility of-a sovereign debt workout mechanism based on some combination of national statutes and international treaty is much stronger now than it was 10 or 20 years ago. This is especially true for the euro zone, where the case for such a regime is particularly strong and its implementation as a complement to the existing European Stability Mechanism would be comparatively straightforward.

As background for the logical structure of this report, it is useful to briefly recall the SDRM discussions of the early 2000s. The main focus of this debate was the perceived trade-off between ex-post and ex-ante efficiency. SDRM proponents based their proposal on ex-post inefficiency, exemplified by the successes or near-misses of holdout creditors in cases against Brazil and Peru. ${ }^{3}$ The argument was that if creditors could expect holdout strategies to pay off, free riding would become

\footnotetext{
${ }^{1}$ For a survey, see Rogoff and Zettelmeyer (2002).

${ }^{2}$ See, e.g., Gianviti et al (2010), Weder di Mauro and Zettelmeyer (2010); EEAG (2011); Bogdandy and Goldmann (2012); and Miller and Thomas (2013).

${ }^{3}$ Panizza, Sturzenegger, and Zettelmeyer (2009); Schumacher, Trebesch, and Enderlein (2012).
} 
overwhelming, rendering orderly debt restructurings unfeasible. Conversely, SDRM critics focused on ex-ante efficiency. They argued that since governments could not be easily forced to pay their debts, sovereign debt was feasible and affordable only because sovereign debt crises were costly. A sovereign debt restructuring mechanism whose express purpose was to lower the cost of debt crises might do more harm than good by lowering incentives to repay and sharply raising the cost of debt.

In principle, there was a way of balancing the trade-off between ex-post costs and ex-ante incentives: an SDRM involving a "double trigger"namely, the debtor country would be able to make a request for assistance (analogous to filing for bankruptcy protection), and a bankruptcy courtlike institution could reject frivolous requests. However, from the perspective of SDRM critics, this solution had two weaknesses. First, private creditors might not trust the bankruptcy courtparticularly if it were the IMF, which was viewed as both susceptible to political pressure and subject to conflicts of interests through its own role as a large creditor. Second, perverse incentives created by lower crisis costs might extend beyond incentives to repudiate-encompassing a broad range of precrisis policies that influenced the chances of getting into debt-servicing difficulties. Hence, to create good incentives for debtor countries, an international bankruptcy court would need to not only distinguish between an "ability to pay" and a "willingness to pay" crisis but also judge whether an "ability to pay" crisis were mainly the fault of the country or the result of bad luck. This was viewed as a tall order for any institution-particularly those that might not be fully independent, and that might be sympathetic to a country's plight regardless of its causes.

The SDRM was rejected in 2003, in part because the United States and large emerging market borrowers could not be convinced that its ex-post benefits outweighed its ex-ante risks, and partly because the ex-post costs of the status quo did not seem intractable at the time; most debt crises since the mid-1990s had been resolved fairly quickly without statutory bankruptcy, and did not lead to litigation by holdouts. Those who worried about holdouts, in lieu of a treaty change, got market-wide contract reform, whereby collective action clauses were introduced in most New York law bonds issued beginning 2003. This was rationalized as a small step toward a more ex-post efficient resolution, which was unlikely to upset markets ex ante (and it did not).

Since 2003 there have been three developments that add to, and might have changed the balance of, the set of arguments outlined above. First, research on sovereign debt problems has evolved to take a broader and somewhat different view of the "ex-ante problem." As an empirical matter, the traditional enforcement problem seems to be overshadowed by moral hazard problems of a different kind. Debtor countries have control over key factors-their debt levels, debt structure and prospects for economic growth-that determine their ability to pay. Additional moral hazard problems may be created at the expense of third parties. These problems can result in overborrowing, along with delays in seeking unavoidable sovereign debt restructurings. The consensus seems to have shifted away from the fear that countries might restructure opportunistically to the fear that they might restructure too late, and that these restructurings might not be deep enough. This has fundamental implications for the debate on sovereign bankruptcy: If the main problem in sovereign debt is not repudiating debtors and overly tight borrowing constraints, but rather overborrowing at the front end and procrastination at the back end, then the old trade-off between ex-ante and ex-post efficiency no longer holds, at least within some range. Lowering the costs of debt crises ex post might benefit efficiency ex ante.

Second, the holdout problem has experienced a rejuvenation. One of the arguments against the SDRM was that it was a heavy-handed way of addressing a problem-coordination failures in debt restructuring-that could be solved easily using procedures and legal techniques that debtors could 
invoke unilaterally. For example, take-it-or-leave-it debt exchange offers, backed by minimum participation thresholds and exit consents, allowed debtors to strip holdouts of enforcement weapons with the agreement of a simple majority of bondholders. However, recent court rulings against Argentina in New York give creditors tools to overcome such tactics. At the same time, bond contracts have developed to require supermajorities for the most powerful exit amendments, which are no longer as potent a solution as they were in the restructurings of the early 2000s. Further, investors pursuing holdout strategies have become increasingly effective, as a function of both their financing and their legal sophistication. As a result, successful debt restructurings have become harder to achieve, even if they are in the interests of both the debtor and a large majority of creditors.

Third, the important special case of the euro area now looms large. This has characteristics that both aggravate the ex-ante problem and increase the plausibility of a statutory solution. The close economic, financial and political linkages inside the euro zone-including, perhaps most important, the threat that a sovereign default might trigger a costly exit from the single currency-make the members of the common currency area much less willing to risk a failed debt restructuring in their midst. On top of this, the lack of monetary and exchange rate instruments at the country level makes it harder for these members to address growth and competitiveness problems without external support. For both reasons, the euro zone suffers a more severe moral hazard problem than, say, the potential moral hazard caused by IMF crisis lending. This may contribute to mispricing, overborrowing and delays in needed sovereign debt restructuring, as occurred in Greece. At the same time, because so many areas of economic policy in the European Union, and particularly in the euro area, are already governed by common statute, a statutory approach toward sovereign bankruptcy may stand a better chance in the euro area than elsewhere.

The remainder of this report follows the structure of these three arguments. We begin with a survey of shifting views on the pathologies in sovereign debt. We next discuss the impact of recent litigation and changes in bond contracts on ad hoc debt restructurings. This is followed by a chapter that argues why a more systematic approach to sovereign debt restructuring might be particularly needed in the euro area. The final chapter presents a number of proposals that could address the problem. These include a proposal to modify the 2012 treaty establishing the European Stability Mechanism (ESM) to require debt restructuring as a condition of ESM assistance in predefined circumstances, and to immunize the assets of those countries that have undergone ESM-sanctioned restructurings from attachments by holdout creditors. At the broader international level, the report presents and discusses three alternative optionstwo that would involve contractual or statutory changes in major borrowing jurisdictions, and one involving an IMF-based restructuring mechanism. The latter envisages endorsement of a sovereign debtor's restructuring proposal by both a majority of creditors and the IMF. Following this double endorsement, the debtor's assets would become immune from attachment in the jurisdictions of IMF members.

The report does not discuss two important topics. First, because it focuses on sovereign debt, it does not deal with how to unwind or prevent excessive debts incurred in the private sector. ${ }^{4}$ However, the links between these problems and sovereign debt problems are briefly discussed in the context of the euro area (chapter 3). The argument is that while the proposals made in this report will not by themselves solve private sector debt problems,

\footnotetext{
${ }^{4}$ Some of these problems, particularly as pertaining to private debt accumulation fueled by international capital flows, were discussed in last year's CIEPR report, Banks and Cross-Border Capital Flows: Policy Challenges and Regulatory Responses (CIEPR 2012).
} 
they may ameliorate them; markets will be more likely to "price" sovereign default risks regardless of whether these originate from sovereign debt or socialized private debt. This should give incentives to sovereigns to worry more about credit booms that could give rise to quasi-fiscal liabilities. While the proposals in this report and plans to create a euro area-based Banking Union address different problems, these problems are linked, and the proposals should be viewed as complementary.

Second, we do not discuss a class of ideas that have broadly similar aims as the proposals in this report, namely, how to prevent sovereign debt crises through debt contracts with equity-like features, for example, by indexing repayments to gross domestic product (GDP) or commodity prices. ${ }^{5} \mathrm{Al}$ though we are sympathetic to these ideas, for the purposes of the present report we take it as a given that in spite of periodic calls, bonds with these features do not play an important role in sovereign finance, and are unlikely to play such a role anytime soon-in part for reasons analyzed in chapter 2 .

The focus of this report is on mechanisms that are plausible today-mechanisms that would allow for the swift renegotiation of debt under certain conditions, in ways that not only make crises less costly but also encourage sovereign debtors and creditors to act more responsibly in normal times.

${ }^{5}$ See, e.g., Mody (2013). 


\section{снаттев2: Pathologies in Sovereign Debt}

key feature distinguishing sovereign debt contracts from debt owed by private parties is weaker contract enforcement. In a sovereign default, the remedies at the disposal of creditorsparticularly private creditors-are limited by the fact that most sovereign assets are located within a sovereign's jurisdiction and cannot be seized, even when creditors have won in court (see chapter 3 ). In spite of this fact, many sovereigns have historically been able to borrow large amounts of funds. ${ }^{6}$ How is this possible? Why would private debtors entrust sovereigns with their money when they cannot enforce repayment?

Inspired by this puzzle, the modern economic literature on sovereign debt, which developed in the 1980s, initially focused on understanding why sovereign debt ever got repaid. It concluded that borrowers repay because defaults are economically costly for the debtor country. ${ }^{7}$ Countries will be able to borrow up to the point in which the temptation to default is balanced by its costs. In standard theories of sovereign debt, this level of debt is generally below the level at which countries would like to be able to borrow.

It follows that attempts to reduce the costs of default could also reduce welfare because they would make sovereign debt more expensive and lower the maximum level of debt that a sovereign can accumulate. Conversely, attempts to improve enforcement could improve welfare even if they make debt crises more painful and protracted. This logic has led some researchers to warn that proposals aimed at reducing the ex-post costs of debt crises could backfire. ${ }^{8}$ It is thus important to also examine policy proposals in the area of crisis resolution from an ex-ante perspective-taking into account their likely impact on the sovereign debt market in normal times-rather than simply from the perspective of whether they will reduce the costs of a crisis once this has happened. The present report takes this perspective throughout.

At the same time, it is important to realize that in spite of the enforcement problem in sovereign

\footnotetext{
${ }^{6}$ According to the IMF's World Economic Outlook (April 2013 edition), general government debt in 2012 stood at about 35 percent of GDP on average in emerging markets and developing countries and over 100 percent of GDP in advanced countries.

${ }^{7}$ The contributions include Eaton and Gersovitz (1981); Sachs and Cohen (1982); and Bulow and Rogoff (1989a, 1989b). For surveys of the literature, see Panizza, Sturzenegger, and Zettelmeyer (2009); Wright (2011); Das, Papaioannou, and Trebesch (2012); Tomz and Wright (2013); and Aguiar and Amador (forthcoming). For evidence on the costs of default, see Mitchener and Weidenmier (2005); Tomz (2007); Borensztein and Panizza (2009); Sandleris (2012); Tomz and Wright (2013); and Cruces and Trebesch (2013).

${ }^{8}$ See Dooley (2000) and Shleifer (2003).
} 
debt, it is logically possible to make crisis resolution more efficient without making debtors countries worse off in normal times. There are two reasons for this:

- Even if there is a trade-off between ex-ante incentives to repay and the ex-post costs of default, this does not mean that this tradeoff cannot be ameliorated. In principle, it could be possible to improve contracts or institutions governing sovereign debt in a way that reduces crisis costs while maintaining incentives to repay.

- Furthermore, there could be important cases in which there is no trade-off between reducing the ex-post costs of crises and improving ex-ante incentives. For example, the costs of default could be a result of historic institutions or contracts that are not optimal in the sense of providing just the right amount of deterrent to stop creditors from repudiating. Or the situation might be complicated by incentive problems that go beyond the enforcement problem. Distorted incentives could drive a wedge between the maximum that a sovereign can borrow-the borrowing limit-and what it should be borrowingthe socially optimal amount of borrowing. If this were to be the case, reducing the costs of crises might not have any social cost ex ante. In fact, for countries that "overborrow"-in the sense that actual borrowing is above the socially optimal amount-tighter borrowing constraints would improve welfare.

The first point has been understood since at least the late 1980s. ${ }^{9}$ Suppose that it were possibly to write contracts (implicitly or explicitly) or create institutions so as to make sovereign defaults costly if and only if they cannot be "excused" by shocks to fundamentals outside the control of debtor countries. That is, repudiations would be severe- ly punished (and as a result, would never occur), while shocks to debt service capacity would lead to a corresponding adjustment in the debt burden without any punishment. In such a world, costly debt crises would never arise, in spite of the presence of an enforcement problem.

In the real world, however, debt crises cannot be neatly separated into excusable defaults driven by fundamentals and inexcusable repudiations. Yet there may be institutional or contractual improvements-for example, debt contracts that index repayments to variables such as international commodity prices-that reduce the frequency or costs of debt crises. The main insight is that costly crises are never just a reflection of the enforcement problem, but also reflect a combination of the enforcement problem with other problems, such as imperfect information or incomplete contracts. As such, it may be possible to reduce the costs of crises through institutions or contracts that legitimize debt restructurings in certain circumstances (which would obviously exclude strategic defaults). This is the flavor of some of the proposals made in the final chapter of this report.

The second point is less well understood, is potentially more controversial, and as such is the main focus of this chapter. It relates to the existence of pathologies in sovereign debt that go beyond weak contract enforcement, and the possibility that these additional pathologies may be more relevant as drivers of actual borrowing behavior. These pathologies include political failures, the moral hazard associated with the presence of international bailouts, and a lack of seniority in sovereign debt contracts. Together, they could be a source of overborrowing and suboptimal public debt management. Political considerations and inefficient contract design may also lead to a situation in which, rather than defaulting too much and too early, countries default too late and too little. In this case, reducing the costs of default will be good not only ex post-once a crisis has occurred-but

\footnotetext{
${ }^{9}$ See Grossman and Van Huyck (1988).
} 
also ex ante, by reducing inefficient borrowing in normal times and making debt crises less likely.

\section{Overborrowing}

In standard economic theories of sovereign debt, sovereigns are credit-constrained because their ability to borrow is capped by a level that depends on default costs. The typical situation in these models is "underborrowing," in the sense that debt levels are suboptimally low from a social perspective. Specifically, debt levels are lower than what a country would want to borrow in a world where debt contracts could be enforced in the same way as, for example, corporate debt contracts.

This view of sovereign debt is difficult to reconcile with actual borrowing behavior, both across countries and over time. Figure 1 shows 2012 general government debt levels for three groups of countries that are roughly similar, within each group, with respect to per capita income levels and (in the case of the two emerging market groups) geography and trading partners. Of the countries shown, only two (Greece and Jamaica) do not currently have access to international capital markets. Of course, the fact that a country has access to capital markets does not mean that its debt may not be primarily determined by its debt limit; these countries may want to stay somewhat below their maximum borrowing in order to have room to respond to economic shocks. The question is whether the data pattern observed in figure 1 is consistent with this notion.

Figure 1 shows that advanced economies tend to have higher debt levels than emerging market countries. ${ }^{10}$ This is consistent with the view that

Figure 1. General Government Debt in Three Groups of Countries, 2012 (percentage of GDP)

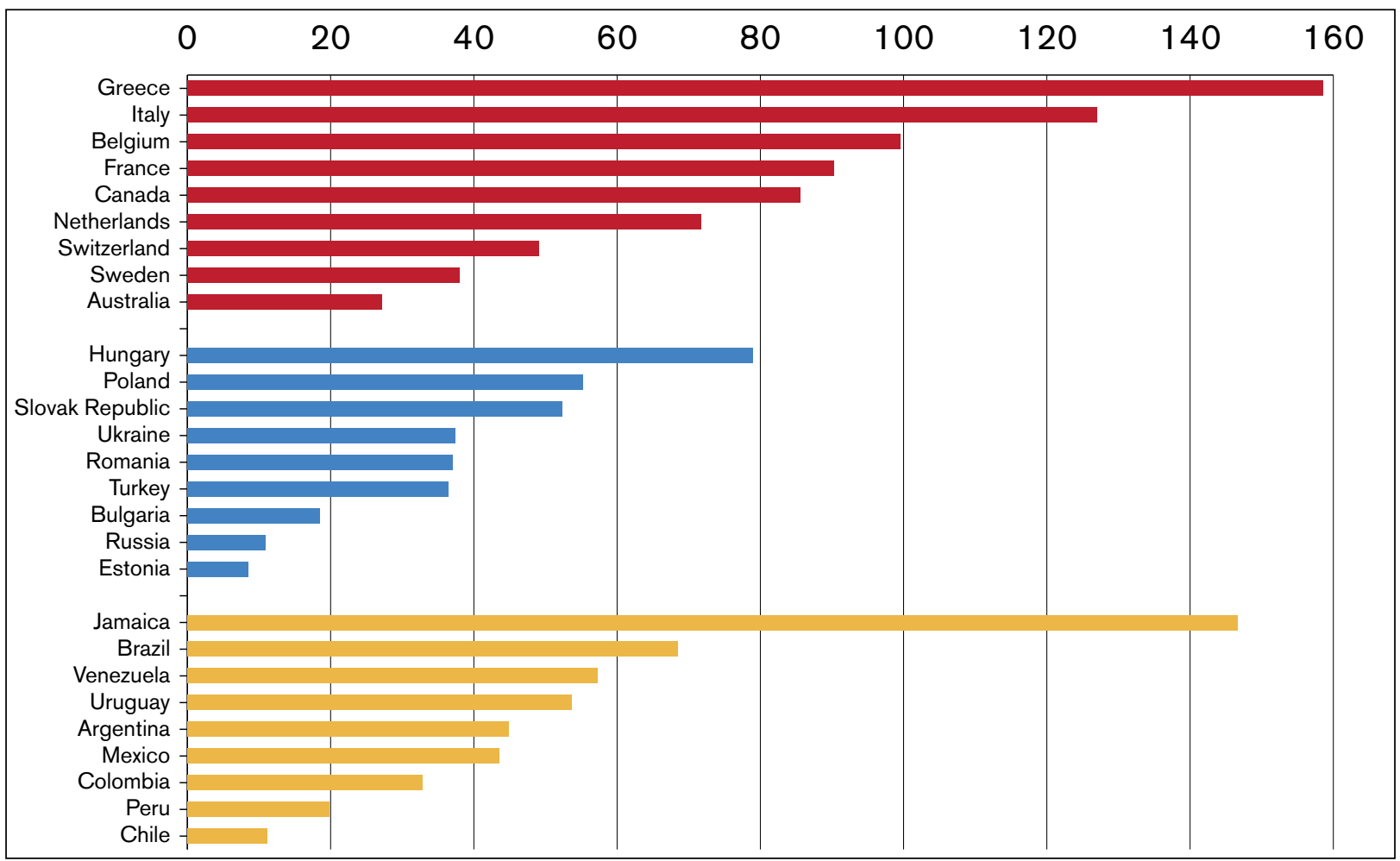

Source: IMF, World Economic Outlook database, April 2013.

\footnotetext{
${ }^{10}$ This is true not only for the average of advanced countries and emerging markets selected in figure 1 for illustrative purposes but also more generally.
} 
debt levels are determined by repayment prospects; advanced countries may be able to borrow in larger amounts because they are institutionally better able to commit to debt repayment, or because they are less likely to suffer shocks that would put their debt levels over the limit where debt restructuring is optimal. However, within the three groups, variations in debt levels (even ignoring Greece and Jamaica, the two outliers) are so large as to be irreconcilable with the view that most of these countries are borrowing at or close to their debt limits. It is implausible that countries' differences in commitment credibility, the location of their assets, their degree of international integration, their dependence on foreign capital or other factors that could drive differences in their borrowing limits could also explain, for example, why Canadian debt is at 86 percent of GDP while Australian debt is only 27 percent, why Italy's debt is 127 percent of GDP while that of the Netherlands is only 71 percent, why debt is only 19 percent of GDP in Peru but 45 percent in Argentina and 68 percent in Brazil, or why debt stands at 19 percent of GDP in Bulgaria but 37 percent in Romania.

Similar arguments apply over time. Belgium increased its debt level from about 75 percent of GDP in 1980 to almost 140 percent in 1993 and subsequently reduced it again to 87 percent in 2007. Over the same period, the French government's debt more than quadrupled as a share of GDP, rising more or less continuously, from about 20 percent to about 90 percent. Peru halved its government debt between 2000 and 2012. So did Sweden. In all these cases, it is difficult to imagine that these swings were the result of tighter or laxer sovereign borrowing constraints. It is more plausible that most of these countries were far from their borrowing limits during most of their histories, and that debt levels changed as a result of policy choices and economic shocks, which affected growth and determined the size of government deficits and debts.
If one accepts the fact that for most advanced and emerging market economies debt levels are determined not by the maximum amount that these countries can borrow but instead by policy choices over time, it is possible, in principle, that countries may, from a social perspective, be overborrowing rather than underborrowing - that is, they may be borrowing beyond the point at which the social cost of one additional unit of debt equals the social benefit of an additional unit of debt-financed government expenditure. Overborrowing could arise from at least three distortions.

First, policymakers often have incentives to borrow more than what is socially optimal (for a recent survey, see Eichengreen et al. 2011). Political failures can also lead to debt crises through suboptimal debt management. Contingent debt instruments with contractual obligations that are linked to a country's ability to pay can help in ensuring that a government meets its financing needs and payment obligations at the lowest possible cost consistent with a prudent degree of risk (Missale 1999). However, self-interested politicians have limited incentives to issue contingent debt instruments that have upfront costs but may yield benefits for their successors. ${ }^{11}$

Second, overborrowing might be the result of moral hazard linked to the presence of an international lender of last resort. Because countries tend to repay what they borrow from official lenders, there is limited empirical evidence for debtor moral hazard at the expenses of global taxpayers. Creditors, however, may have incentives to behave recklessly and lend without adequate regard to risk because official bailout packages may allow for repayments that are "too high" with respect to the social optimum. The bill is not footed by global taxpayers but by local taxpayers who end up repaying, even when it would have been better to restructure (Jeanne and Zettelmeyer 2001). Although, in principle, moral hazard can be mitigated by designing

\footnotetext{
${ }^{11}$ While political failures limit the supply of contingent debt instruments, market failures associated with coordination problems limit the
} demand for such instruments. 
official rescue packages that "bail-in" private creditors, such bail-ins may not be optimal ex post, and it may be difficult for official lenders to commit to them ex ante. Official packages can also delay the moment when a country decides to restructure its debts (more is given on this below), making creditors willing to provide short-term finance to risky creditors in the hope of being able to collect before the country defaults or starts the restructuring process.

Third, overborrowing could result from the fact that, in the absence of seniority rules, new lending to high-risk countries dilutes the claims of existing creditors. Debt dilution can lead to excessive debt accumulation because the marginal interest rate does not reflect the increase in risk brought about the issuance of new debt (Bolton and Jeanne 2007). Countries with prudent fiscal policies face the opposite problem because the possibility of diluting the debt increases the risk of lending to these countries. Debt dilution has also an adverse effect on debt composition because, in the attempt to hold debt that is difficult to dilute, lenders will be reluctant to buy long-term securities or local currency debt instruments (Borensztein et al. 2005). ${ }^{12}$

Overborrowing requires creditors in the private or official sector that agree to provide the needed financing. Overborrowing is often facilitated by herding behavior, which leads creditors to take on too much risk during periods of global optimism. ${ }^{13}$ Though most theoretical models of sovereign debt suggest that countries should borrow abroad during recessions and repay during good times, there is evidence that net lending to emerging market and developing countries is pro-cyclical, with large capital inflows during periods of high growth and outflows during recessions (see Panizza, Sturzenegger, and Zettelmeyer 2009, table 2).
This is also true for cross-border, bank-intermediated private credit flows (CIEPR 2012).

In the stereotypical case of overborrowing syndrome, economic reforms and financial liberalization are followed by rapid and unsustainable capital inflows channeled to the private sector by domestic banks and fueled by excessive optimism among residents, foreign investors and policymakers (McKinnon and Pill 1996). A global shock, or the realization that the inflows are not sustainable, is often followed by a sudden stop (Calvo 2005), economic collapse and financial crisis. At this point, private sector liabilities are transferred to the sovereign, exacerbating the impact of public overborrowing during the preceding upswing.

As suggested by figure 1, in the advanced economies, the credit constraints associated with enforcement problems are unlikely to be binding at levels that are sufficiently low to rule out overborrowing. Many advanced economies have been able to accumulate large public debts, and, until recently, there was no strong relationship between debt levels and the borrowing costs faced by this group of countries. This remains true for the advanced economies that do not belong to the euro area (see chapter 4$){ }^{14}$

In emerging market countries, debt ratios tend to be lower, and the correlation between borrowing costs and fundamentals is tighter than in the advanced economies. Low debt ratios are consistent with the presence of credit constraints associated with limited enforcement. However, a limited ability and willingness to borrow may also be due to the fact that emerging market countries have weaker institutions (Reinhart, Rogoff, and Savastano 2003), have riskier debt structures (Eichengreen et al. 2005), and face larger external financial shocks (Calvo 2005).

\footnotetext{
${ }^{12}$ Dilution accounts for more than 80 percent of the default risk in the baseline calibrated model of Hatchondo, Martinez, and Sosa Padilla (2012).

${ }^{13}$ In the presence of rational herding, investors disregard fundamentals and stand ready to either lend at will when everybody else is lending or to liquidate good credits when everybody else is also selling (see Allen, Morris, and Shin 2006).

${ }^{14}$ For an econometric analysis, see Dell'Erba, Hausmann, and Panizza (2013).
} 
Table 1. Selected Bond Issuances in Frontier Markets

\begin{tabular}{|c|c|c|c|c|c|c|}
\hline Country & Date & $\begin{array}{c}\text { Amount } \\
\text { (millions of dollars) }\end{array}$ & Currency & $\begin{array}{c}\text { Yield } \\
\text { (basis points) }\end{array}$ & $\begin{array}{l}\text { Maturity } \\
\text { (years) }\end{array}$ & $\begin{array}{l}\text { Rating } \\
(\text { S\&P })\end{array}$ \\
\hline Angola & $08 / 2012$ & 1,000 & dollar & 700 & 7 & BB- \\
\hline Bolivia & $10 / 2012$ & 500 & dollar & 490 & 10 & BB- \\
\hline Honduras & $04 / 2013$ & 500 & dollar & 750 & 10 & $\mathrm{~B}+$ \\
\hline Mongolia & $11 / 2012$ & 1,000 & dollar & 512 & 10 & BB- \\
\hline Mongolia & $11 / 2012$ & 500 & dollar & 412 & 5 & BB- \\
\hline Paraguay & $01 / 2013$ & 500 & dollar & 460 & 10 & $\mathrm{BB}-$ \\
\hline Rwanda & $04 / 2013$ & 400 & euro & 660 & 10 & B \\
\hline Tanzania & $02 / 2013$ & 600 & dollar & $\mathrm{LIBOR}^{\mathrm{b}}+600$ & 7 & NR \\
\hline Zambia & $10 / 2012$ & 750 & dollar & 560 & 10 & $\mathrm{~B}+$ \\
\hline $\begin{array}{l}\text { Memo: } \\
\text { Investment-grade } \\
\text { U.S. corporates }{ }^{c}\end{array}$ & $2011-13$ & & dollar & 450 & $10-15$ & \\
\hline
\end{tabular}

aStandard \& Poor's.

bLondon Interbank Offered Rate.

'BofA Merrill Lynch U.S. corporate 10-15 year effective yield.

Although emerging market countries do face precarious access to credit, the presence of generalized capital flows bonanzas and sudden stops suggests that global factors may be a more important determinant of credit constraints than country-specific considerations linked to capacity and willingness to pay (Calvo, Leiderman, and Reinhart 1993; González-Rozada and Levy Yeyati 2008). For instance, in a context of historically low interest rates, investors have been willing to take greater risks to achieve returns. This "search for yield" allowed low-rated frontier markets to issue international bonds with low spreads compared with higher-rated instruments issued by traditional borrowers (table 1).

\section{Restructuring Too Late}

There is evidence that policymakers are often reluctant to restructure their debts and suboptimally postpone unavoidable defaults (e.g., Borensztein and Panizza 2009; Levy Yeyati and Panizza 2010; IMF 2013). Delayed defaults can lead to the destruction of value because a prolonged predefault crisis may reduce a country's capacity and willing- ness to pay. Its capacity to pay is reduced because procrastination prolongs the climate of uncertainty, high interest rates and restrictive fiscal policies that are ineffective in avoiding default but amplify output contractions. Delayed defaults reduce its willingness to pay because electors that have suffered long periods of economic austerity are less likely to support a creditor-friendly debt restructuring.

Because policymakers are often replaced after a debt default (figure 2), late restructurings may be caused by self-interested agents that have incentives to gamble for redemption, even when delays entail economic costs for society as a whole. Myopic policymakers who do not take into account the long-run costs of excessive debt accumulation may also decide to delay a default in order to have continuous access to external resources. Short political horizons may also create incentives to undertake policies that increase the vulnerability of the financial sector to government default. This generates short-term benefits in terms of a higher capacity to borrow, but at the expense of higher future default costs if the accumulated debt turns out to be unsustainable (Acharya and Rajan 2013). 
Figure 2. The Probability of Replacing the Minister of Finance Given Various Events

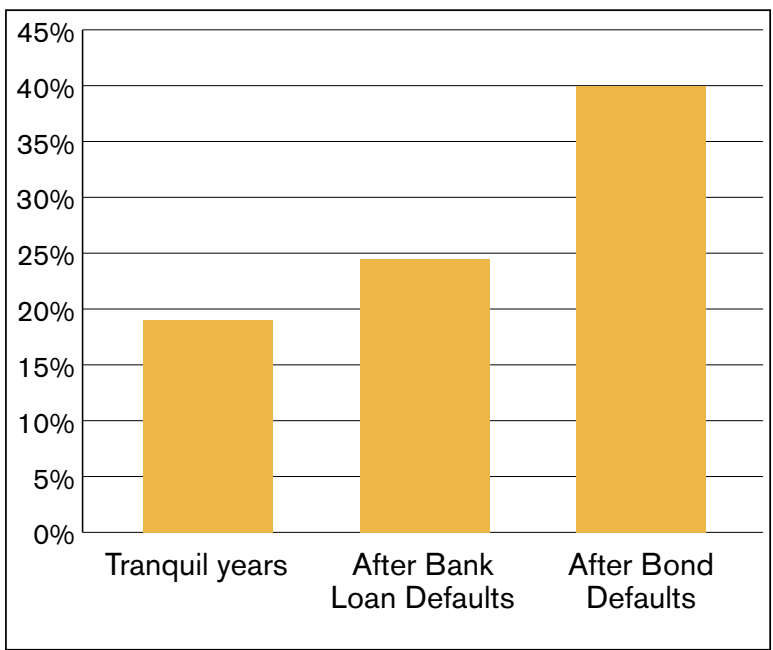

Source: Borensztein and Panizza (2009, table 11).

Alternatively, policymakers who believe that "strategic" defaults can have large reputational costs but that "unavoidable" defaults carry limited costs in terms of reputation may decide to postpone a needed default in order to signal that the default is indeed unavoidable. Finally, policymakers may delay necessary defaults because, in the absence of a clear mechanism to manage the restructuring process, they overstate the actual costs of default.

The IMF (2013) describes several episodes in which a country decided to initiate a restructuring process years after IMF staff had judged the debt situation to be unsustainable. In the majority of these cases, the countries decided to restructure and approach the International Monetary Fund only when they lost market access. There are, however, also cases in which delays were facilitated by official sector financing to countries that had lost market access and were facing unsustainable debt situations. ${ }^{15} \mathrm{~A}$ willingness to provide official financing to countries that face an unsustainable situation is sometimes driven by private creditors' lobbying, especially if the restructuring could lead to large losses for banks located in official lenders' countries, or due to the fear that a restructuring would trigger global market turmoil (IMF 2013).

\section{Restructuring Too Little}

In the late 1990s, it was feared that the process of debt securitization sparked by the Brady exchanges would amplify creditors' coordination problems and lead to long and litigious negotiations. However, by and large (Argentina's 2005 restructuring is a notable exception; see the next section), these fears did not materialize. The duration of the average default episodes is now much shorter than in the 1980s (Inter-American Development Bank 2006; Bi, Chamon, and Zettelmeyer 2011; Trebesch 2013).

Quick debt restructurings with attractive offers, however, can lead to insufficient debt reduction and may not restore debt sustainability. The current system may thus generate two, equally bad, equilibria (Powell 2011). In the first equilibrium, countries implement quick and creditor-friendly restructurings but do not solve their debt-sustainability problem. The second equilibrium can deliver larger debt relief at the cost of long negotiations and protracted litigation. Evidence showing a positive relationship between haircuts (i.e., the losses faced by bondholders during debt restructuring episodes) and the duration of restructuring episodes (figure 3 ) and the bimodal distribution of haircuts (figure 4) is consistent with such a view (Powell 2012).

\footnotetext{
${ }^{15}$ Greece is an example. According to the IMF's $(2013,20)$ own assessment: "The case of Greece is also illustrative of the difficulty of introducing early debt restructuring. Even in the face of a sustained loss of market access, debt restructuring could be delayed because of the ample availability of official financing and the authorities' stated willingness to entertain an unprecedented program of fiscal adjustment. Even under these supportive conditions, however, it was not possible to establish that there was a high probability of debt sustainability as required by the exceptional access policy. The chosen course was therefore to amend the policy to create an exception to the requirement of "high probability" in circumstances where "there is a high risk of international systemic spillovers." Eventually, the planned adjustment proved unfeasible and, despite additional official sector financing on supportive terms, private debt restructuring became unavoidable and was launched in February 2012." There have been, however, also cases in which official financing and adjustments have been successful in restoring debt sustainability while avoiding a full-fledged debt restructuring. Turkey in the early 2000s is an example of a situation in which official financing was successful in addressing a nearly unsustainable debt situation (IMF 2013).
} 
Political distortions can amplify these problems. Myopic policymakers who want to quickly access the international capital market and do not internalize the costs of future defaults may decide to advocate the implementation of quick and creditor-friendly restructurings. Equally myopic policymakers who do not need access to the international capital market may instead decide to be excessively tough with their creditors and hurt the country's international reputation.

The official sector sometimes serves to exacerbate the problem through some bias stemming from myopia or overoptimism. Some of the restructuring episodes described by the IMF (2013) were based on overoptimistic debt sustainability assessments, with relatively small face-value haircuts that did not restore debt sustainability, required prolonged official support and led to additional restructurings. ${ }^{16}$ Problems associated with suboptimal haircuts are amplified by the fact that haircuts and debt relief are different concepts. Haircuts are usually calculated by comparing the present value of old and new debts obtained by discounting future payments with the exit yield (i.e., the interest rate faced by the country when it completes the restructuring process). ${ }^{17}$ However, countries should evaluate their debts by using the interest rate that they expect to prevail in noncrisis times. Sturzenegger and Zettelmeyer (2007) apply this idea to a series of debt restructuring episodes that took place between 1998 and 2003 and show that the debt relief of these restructuring episodes is significantly smaller than the losses suffered by investors.

Figure 3. The Longer the Restructuring Negotiations, the Heavier the Haircut

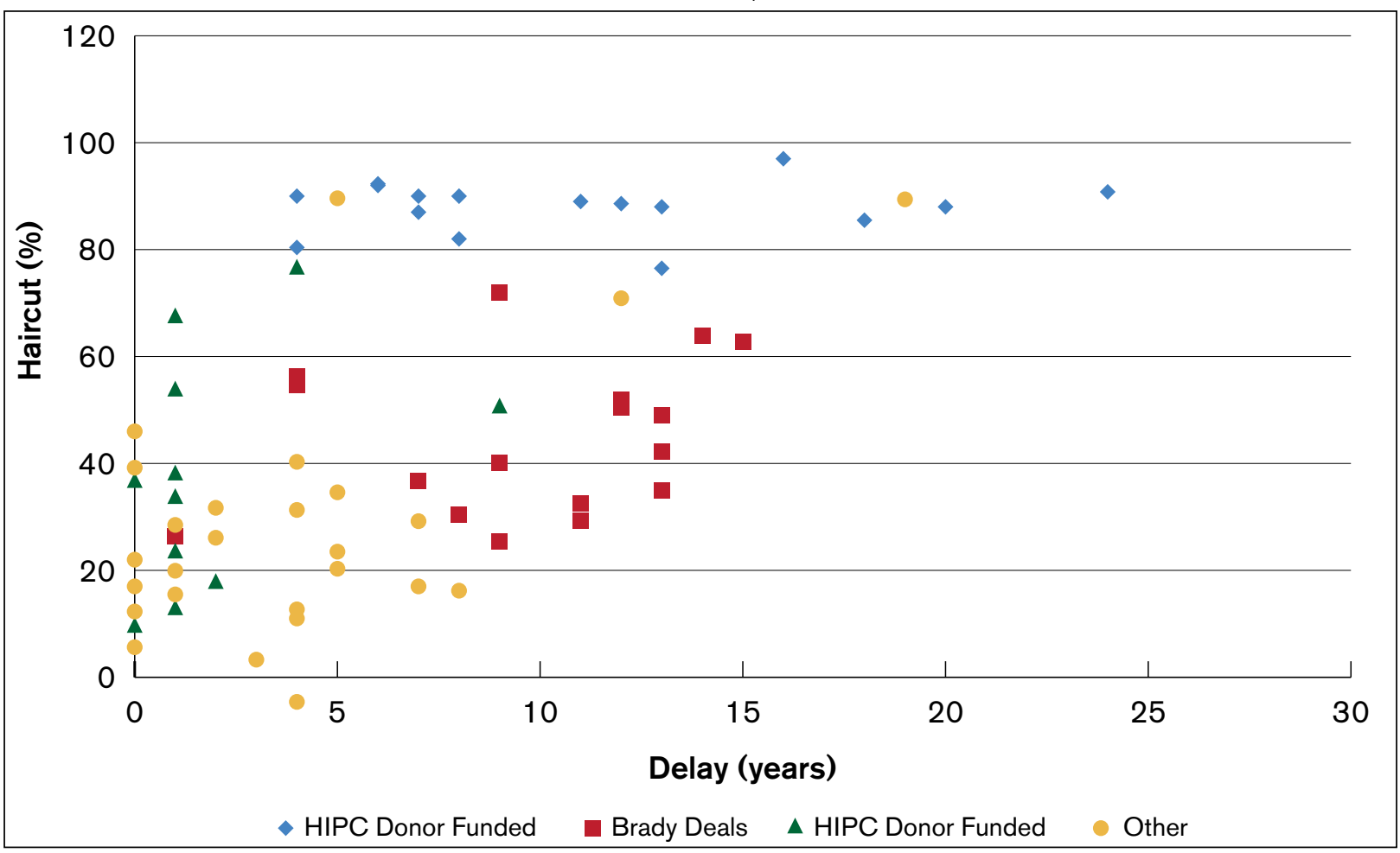

Note: $\mathrm{HIPC}=$ Heavily Indebted Poor Countries initiative. Sources: Powell, Sandleris, and Tavella (2013); Tavella (2013).

\footnotetext{
${ }^{16}$ However, there are also a few cases in which restructurings exercised that were deemed to be too timid ended up being successful in restoring debt sustainability. One example is Uruguay's 2003 debt restructuring that, according to a 2006 assessment, was deemed to have left significant debt vulnerabilities (IMF 2006).

${ }^{17}$ Formally: $\mathrm{H}^{\mathrm{sz}}=1$ - Present Value New Debt (r) / Present Value Old Debt (r), where $\mathrm{r}$ is the exit yield.
} 
Figure 2. The Probability of Replacing the Minister of Finance Given Various Events

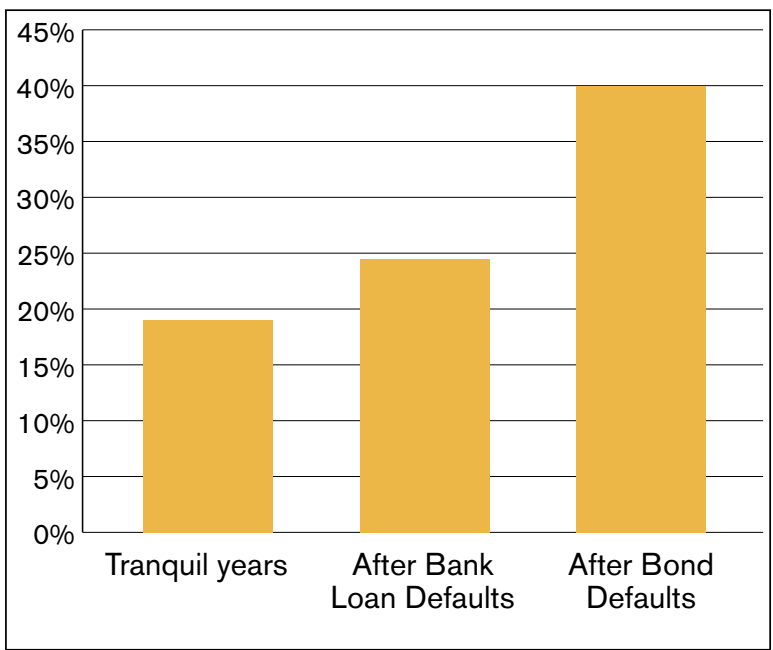

Source: Borensztein and Panizza (2009, table 11).

Alternatively, policymakers who believe that "strategic" defaults can have large reputational costs but that "unavoidable" defaults carry limited costs in terms of reputation may decide to postpone a needed default in order to signal that the default is indeed unavoidable. Finally, policymakers may delay necessary defaults because, in the absence of a clear mechanism to manage the restructuring process, they overstate the actual costs of default.

The IMF (2013) describes several episodes in which a country decided to initiate a restructuring process years after IMF staff had judged the debt situation to be unsustainable. In the majority of these cases, the countries decided to restructure and approach the International Monetary Fund only when they lost market access. There are, however, also cases in which delays were facilitated by official sector financing to countries that had lost market access and were facing unsustainable debt situations. ${ }^{15} \mathrm{~A}$ willingness to provide official financing to countries that face an unsustainable situation is sometimes driven by private creditors' lobbying, especially if the restructuring could lead to large losses for banks located in official lenders' countries, or due to the fear that a restructuring would trigger global market turmoil (IMF 2013).

\section{Restructuring Too Little}

In the late 1990s, it was feared that the process of debt securitization sparked by the Brady exchanges would amplify creditors' coordination problems and lead to long and litigious negotiations. However, by and large (Argentina's 2005 restructuring is a notable exception; see the next section), these fears did not materialize. The duration of the average default episodes is now much shorter than in the 1980s (Inter-American Development Bank 2006; Bi, Chamon, and Zettelmeyer 2011; Trebesch 2013).

Quick debt restructurings with attractive offers, however, can lead to insufficient debt reduction and may not restore debt sustainability. The current system may thus generate two, equally bad, equilibria (Powell 2011). In the first equilibrium, countries implement quick and creditor-friendly restructurings but do not solve their debt-sustainability problem. The second equilibrium can deliver larger debt relief at the cost of long negotiations and protracted litigation. Evidence showing a positive relationship between haircuts (i.e., the losses faced by bondholders during debt restructuring episodes) and the duration of restructuring episodes (figure 3 ) and the bimodal distribution of haircuts (figure 4) is consistent with such a view (Powell 2012).

\footnotetext{
${ }^{15}$ Greece is an example. According to the IMF's $(2013,20)$ own assessment: "The case of Greece is also illustrative of the difficulty of introducing early debt restructuring. Even in the face of a sustained loss of market access, debt restructuring could be delayed because of the ample availability of official financing and the authorities' stated willingness to entertain an unprecedented program of fiscal adjustment. Even under these supportive conditions, however, it was not possible to establish that there was a high probability of debt sustainability as required by the exceptional access policy. The chosen course was therefore to amend the policy to create an exception to the requirement of "high probability" in circumstances where "there is a high risk of international systemic spillovers." Eventually, the planned adjustment proved unfeasible and, despite additional official sector financing on supportive terms, private debt restructuring became unavoidable and was launched in February 2012." There have been, however, also cases in which official financing and adjustments have been successful in restoring debt sustainability while avoiding a full-fledged debt restructuring. Turkey in the early 2000s is an example of a situation in which official financing was successful in addressing a nearly unsustainable debt situation (IMF 2013).
} 
Figure 4. Haircuts Seem to Have a Bimodal Distribution

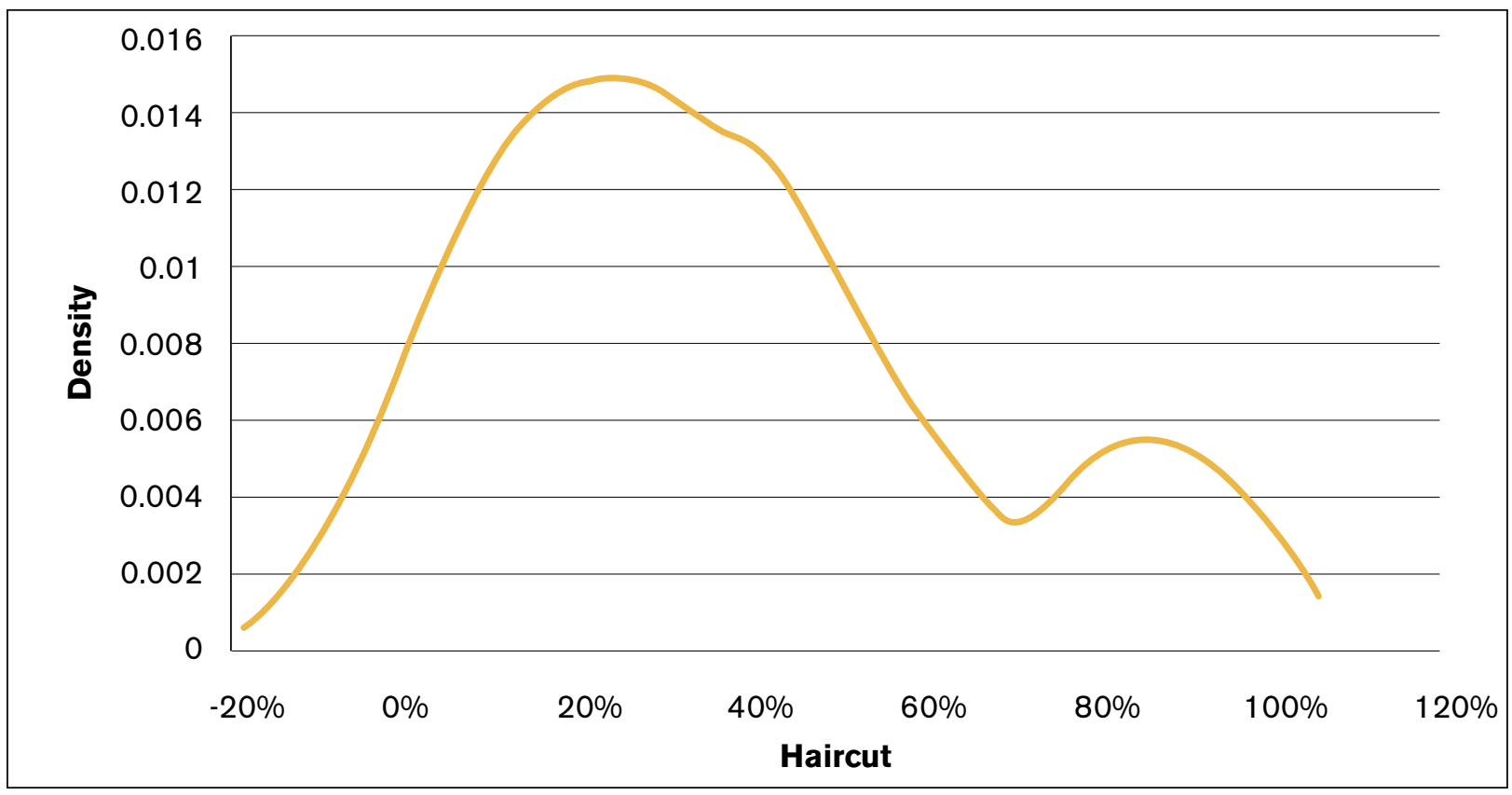

Source: Powell (2012).

\section{Prophylaxis}

If the pathologies described above dominate the classic enforcement problem, a reform that facilitates the debt restructuring process, strengthens incentives for evaluating credit risk, and reduces procrastination could be efficient both ex post and ex ante:

- If easier debt restructuring bolsters incentives to carefully assess country risk, a reform in this direction will increase borrowing costs for countries with unsustainable policies and reduce their ability to accumulate excessive debts. Conversely, a smoother debt restructuring process may benefit (or at least not harm) countries that do not overborrow because, in the case of a large negative shock, investors are likely to obtain higher recovery values (Rogoff 2003). ${ }^{18}$
- A system that guarantees speedy and transparent debt restructurings can also reduce the overborrowing associated with creditor moral hazard because it allows the international financial institutions to resist pressure to lend to countries that face sustainability problems. This will be particularly true if the restructuring process is combined with a clear set of rules that allows for exceptional financing to countries that face liquidity problems but prevent official lenders from providing funds to countries that face an unsustainable debt situation.

- A sovereign debt restructuring framework could also have positive effects on debt composition. Reforms that reduce moral hazard and lead to more careful country-specific risk assessment may provide policymakers with incentives to issue "safer"-from the

${ }^{18}$ A possible caveat is that, in the presence of uncertainty (or other market imperfections), creditors may reduce lending flows to countries with a fully sustainable debt situation. 
point of view of the issuer-debt instruments. Enforceable seniority rules that address debt dilution problems may reduce overborrowing and increase investors' willingness to hold such instruments.

Although marginal improvements to the debt workout process are unlikely to result in inefficiencies ex ante,$^{19}$ it is possible that reform designed to facilitate sovereign debt restructuring could overshoot and, by reducing a country's willingness to pay, raise the borrowing costs of solvent sovereigns. However, the chances that this might happen are contained by the fact that willingness to pay is sustained by the economic costs of default, which are not directly affected by the debt restructuring regime. Besides the political costs of default mentioned above, a large literature suggests that defaults inflict broad "collateral damage" on the debtor country. Defaults may have a negative effect on the country's overall reputation (not just its reputation vis-à-vis its creditors) and increase the costs of all its transactions and agreements (economic and political, domestic and international) that require a substantial amount of trust among the counterparties (Cole and Kehoe 1998). ${ }^{20}$ If such reputational costs are large enough, the country's willingness to pay will be maintained even in the presence of an (ex-post) efficient debt restructuring mechanism. Indeed, a sovereign debt court able to assess ability to pay could create willingness to pay by increasing the reputational costs of strategic defaults and mitigate the delayed default problems by reducing the reputational costs of unavoidable defaults.

To conclude, there are multiple ex-ante problems associated with sovereign debt, and these problems in principle could be reduced through a sovereign bankruptcy procedure, without necessarily exacerbating the enforcement problem. This said, the design of complex mechanisms that can deal with several inefficiencies at once is rife with difficulties and would require significant information and commitment capacity. The last chapter of this report discusses whether such mechanisms might be legally and politically feasible.

\footnotetext{
${ }^{19}$ For evidence showing that collective action clauses do not significantly increase borrowing costs for most issuers, see Eichengreen and Portes (1995); Eichengreen and Mody (2000); and Bradley and Gulati (2012).

${ }^{20}$ An alternative class of models suggests that sovereign defaults may have large economic costs because they reveal negative information on the underlying structure of the economy (Sandleris 2008; Catão, Fostel, and Kapur 2007).
} 


\section{сннртек з: Argentina and the Rebirth of the Holdout Problem}

\section{A Fundamental Tension}

From a legal perspective, there are two noteworthy distinctions between corporate and sovereign debt. First, as already discussed, sovereign debt is mostly unenforceable. This is because sovereign immunity shields most public assets from creditors, even if they win a judgment against a defaulting government. ${ }^{21}$ The debtor's property is either inside its own national borders (where the courts are loath to side with creditors against their own government), or enjoys the special protections that are provided for embassies, central bank funds, military installations and the like. Property used for commercial activity is more accessible, but since the wave of privatizations in the late 20th century, few governments have conducted much commercial business in their own name. Although sovereigns often waive immunities when they borrow abroad, courts sometimes interpret general waivers narrowly or even ignore them. Where the legal scope for enforcement is so limited, political pressures play an outsize role, adding to uncertainty about the outcome of any given case.

Second, although sovereign debt contracts are hard to enforce, they also last forever. Without bankruptcy, sovereign debt cannot be discharged to give the country a fresh start. In most cases, a determined creditor insisting on full repayment cannot be forced to restructure its bonds. At the same time, the combination of immunity and transactional technique that shields debtors from enforcement is imperfect. It relies on diverse national laws and contract provisions. When creditors try to attach external payment flows, the effectiveness of immunity as a shield depends on individual sovereigns' capacity to litigate and survive the loss of market access for potentially long stretches of time. This implies that creditors with the time, will and resources to pursue a country to the ends of the Earth can try to make life difficult for it in perpetuity, throwing obstacles in the way of its international trade and financial activity.

Arguably, the balance between these fundamental characteristics of sovereign debt-the fact that enforcement is difficult and unpredictable, but not absent altogether; and the fact that sovereigns cannot get a fresh start-has made orderly debt restructurings possible in the new era of bonded debt. Faced with the alternatives of accepting a reasonable take-it-or-leave-it debt exchange offer or the hard work and uncertainty of enforcement,

\footnotetext{
${ }^{21}$ E.g., see Weidemaier (forthcoming).
} 
most creditors will accept the offer, particularly when the litigation prospects and secondary market values of defaulted instruments are further eroded by restructuring techniques ( $\mathrm{Bi}$, Chamon, and Zettelmeyer 2011). This calculus may not apply to specialized distressed debt funds-expert litigators-that have the patience, skill and deep pockets to exploit the loopholes in sovereign immunity-provided the sovereign's overall debt stock is reduced to make side payments possible. Sovereigns, in turn, will understand that in the presence of these loopholes, and given the nondischargeability of debt, holdouts can be a permanent source of irritation and disruption. As a result, they will typically settle, and sometimes repay holdouts in full.

Since the revival of the sovereign bond market in the 1990s, the fundamental tension between the lack of enforcement and the lack of a fresh start has produced a regime where few creditors hold out. Those that do hold out do not fundamentally disrupt the restructuring process. With very few exceptions-most notably Argentina, where the authorities took a confrontational stance with creditors, largely for reasons of domestic political economy-all debt exchanges since the return of the emerging markets' sovereign bond market in the early 1990s have conformed to this pattern. As we argued in the previous section, some of these debt exchanges did not go far enough in reducing debt burdens. But they certainly constituted a "technology" for debt restructuring that minimized litigation and exclusion from sovereign debt markets.

\section{The Return of the Holdout}

Those creditors that refused Argentina's restructuring offers have been chasing it around the globe since 2001, using tactics that range from the exotic to the cartoonish. However, recent rulings in New York may give creditors the first broadly replicable remedy against sovereign debtors since the days of gunboat diplomacy a century ago (box 1). Relying on the "pari passu" clause in Argentina's fiscal agency agreement, a group of holdouts secured an order that bars Argentina from making payments on its restructured debt unless it pays holdouts proportionately ("ratably"). Under court orders, if the new bondholders get paid in full under the restructured contracts, holdouts are entitled to full payment under their original contracts.

Because versions of the pari passu clause are present in all sovereign bonds, the ratable payment order in New York has given creditors a way to intercept flows from a wide range of sovereigns to firms and official institutions. For the first time in decades, sovereign debt enforcement looks like a much more realistic prospect in a major financial jurisdiction. This is because cross-border payment flows remain ubiquitous and essential for most sovereigns. The pari passu remedy operates by inflicting collateral damage; that is, those creditors under performing debt contracts are blocked from receiving their payments, and payment and clearing systems and trustees are threatened with contempt of court if they help the debtor pay its performing bonds. ${ }^{22}$ This forces the debtor to choose between repaying holdouts in full and defaulting on creditors within the reach of U.S. courts. The latter, in turn, would imply a loss of access to large segments of the international market, along with possibly interfering with trade-related payments.

In a world of well-coordinated creditors, giving creditors a powerful new enforcement tool might improve welfare. Creditors would enforce debt repayment when it is in their collective interest to do so. This would rule out "rogue debtor" behaviorthat is, instances when countries repudiate their

\footnotetext{
${ }^{22}$ Although the creditors said that they were not trying to block payments to the IMF, the terms of the court orders appear to cover private and official payments in equal measure.
} 
Argentina defaulted on more than $\$ 80$ billion in foreign bonds in 2001 . Two debt exchanges and over a decade later, it has restructured 93 percent of this total. NML Capital, Ltd., is among the creditors that rejected Argentina's offers and sued for full payment. NML is an affiliate of Elliott Associates, which specializes in distressed sovereign debt litigation. Elliott's successful lawsuit against Peru a decade earlier, on the same theory it has since used against Argentina, was prominently cited to support SDRM.

Unlike Peru, Argentina has refused to settle with the holdouts, and it has chosen instead to pay the cost of moving its assets beyond its creditors' reach and to avoid new borrowing abroad, for fear of attachment.

By 2012, both the creditors and the courts were ready to escalate debt enforcement. In February, the U.S. federal judge in New York, who has presided over Argentina's debt litigation all these years, ruled that it had violated the pari passu clause in its old bonds with its protracted failure to pay, by enacting laws that impede settlement, and by making official statements of defiance-among other things. The court required Argentina to pay both its old and new bonds "ratably." The court later elaborated that ratable payments meant that Argentina must pay NML and its co-plaintiffs full principal and pastdue interest (now $\$ 1.4$ billion) whenever it makes the periodic coupon payment on the restructured bonds. The judge prohibited Argentina from rerouting payments on the new bonds, and threatened to sanction third parties that might help Argentina pay this debt but not NML. The threat covers trustees, clearinghouses and payment systems, even naming some located in Belgium, Luxembourg and the United Kingdom. The court effectively gave Argentina only two ways to comply: pay everyone, or default on everyone.

In October 2012, the U.S. Federal Appeals Court for the Second Circuit agreed that Argentina had violated the pari passu clause and must make ratable payments. It dismissed the U.S. executive branch's objections to the lower court's contract interpretation, its warnings that the remedy would impede future restructurings, and its claim that the court had violated the U.S. Foreign Sovereign Immunities Act by telling Argentina how to spend its treasury funds anywhere in the world.

In August 2013, the Second Circuit also affirmed the lower court's formula for ratable payment, and refused to limit up front the injunction's territorial reach, or its potential impact on third parties. The court was unpersuaded by the many submissions from the exchange bondholders and financial institutions potentially subject to sanctions. However, the injunction remains stayed (suspended) for now, to allow appeals to the U.S. Supreme Court. The stay may be at risk in the wake of Argentina's recent announcement that it would offer to swap its restructured New York bonds for domestic debt with payment streams beyond the reach of U.S. courts.

Argentina appealed to the U.S. Supreme Court in June 2013, asking it to review the holding that it may not service its new bonds unless it pays the plaintiffs ratably. France has filed a friend-of-the-court brief urging review, and stressing the consequences for debt restructuring and the Paris Club. In light of the August 2013 court decision, Argentina and other countries are likely to make other submissions to the Supreme Court. The Court is also likely to ask the U.S. government for its views. 
debts or offer creditors a debt restructuring well below their capacity to pay. These have been rare in sovereign debt since World War II, much rarer than the opposite problem of overindebted countries that restructure too little too late, as argued in the previous chapter; however, ruling out rogue behavior entirely surely would be good news, particularly from the perspective of new borrowers with short track records. If, conversely, a debtor is genuinely unable to pay-or debt is inefficiently high, creating a debt overhang problem that weighs on growth and future capacity to pay-creditors could collectively agree to renegotiate debt contracts. Debtors would be discharged of past debt obligations through a change in the contract terms of each and every existing debt obligation.

In the absence of effective creditor coordination, however, the New York decisions could turn out to be a big problem. This is because they are likely to upset the delicate balance between imperfect enforcement and the nondischargeability of debt that has made ad hoc debt exchanges reasonably smooth in the past. Though sovereign debt remains nondischargeable, potential holdouts have been handed a much better enforcement technique than they had in the past: "third party enforcement" directed not at the sovereign itself but at those private parties on which the sovereign depends.

This will make successful debt exchanges harder to coordinate, even when they are in the joint interests of the debtor country and the creditors collectively. On one hand, the bargaining power of potential holdouts will be higher, making holdout strategies a more attractive proposition. One the other hand, creditors considering an exchange offer must weigh not only the proposed haircut but also the prospect of defending a lawsuit or, at a minimum, having their reduced payments interrupted by future holdouts. This means that even where litigation is unattractive to most creditors, participation is likely to become much less attractive.

As a result, exchange offers could fail for lack of participation even when they were collectively optimal, or they could result in much lighter haircuts than would be needed to restore debt sustainability. The country and most of its creditors, and perhaps even its neighbors and other victims of spillovers, could risk getting permanently stuck in debt purgatory.

\section{No Easy Way Out}

The opinions of the U.S. Court of Appeals mistakenly suggest that the court follows on the heels of a major shift in sovereign debt contracts that facilitates restructuring-the advent of collective action clauses (CACs) - which creates the space for more robust enforcement. In this view, the rise of CACs gets the debtor closer to a fresh start and justifies "rebalancing" in the direction of enforcement. However, whereas CACs can be helpful, they do not-at least in the variety that is most common in sovereign debt contracts today-eliminate holdouts in sovereign debt restructuring so as to make the pari passu remedy unimportant. Under the prevailing model of CACs, a supermajority of creditors in a single bond series may vote to amend the terms and bind the dissenting minority. However, creditors can and do target small series trading at a deep discount, where they can buy a blocking position with relative ease, hold out, and threaten to sue. For instance, more than half of all foreign-law bonds in the Greek debt restructuring failed to get the needed votes to amend the terms. These bonds are still being serviced according to the original terms.

Could exit consents offer a solution? Since Ecuador's 2000 restructuring, this has been a popular technique to deter holdouts in sovereign restructuring. When participating creditors exchange their old bonds for new ones, they are asked to vote to amend certain nonfinancial terms of the bond that may be altered by simple majority, with the result binding on all. In the early days of the tactic, it could be used to strip out a bond's terms concerning negative pledge, pari passu, listing, immunity and jurisdiction. Nonparticipants risked staying behind with an illiquid and potentially 


\section{Box 2. The Assenagon Case}

CACs and exit consents both rely on majority rule. When a technique empowers a majority of bondholders to impose restructuring terms on dissenters, it raises the possibility of unfair treatment. Such fairness concerns have featured most prominently in U.K. court cases about the oppression of bondholder minorities. Taken to the extreme, this line of reasoning can block or severely limit the use of CACs and exit consents, and breathe new life into holdout strategies.

The High Court decision in Assenagon Asset Management S.A. and Irish Bank Resolution Corporation Limited (Formerly Anglo Irish Bank Corporation Limited) involved the use of exit consents in an Irish bank's restructuring and recapitalization exercise. Holders of Anglo-Irish bank bonds were invited to exchange their holdings for new ones at 20 cents on the euro. At the same time, they were asked to vote to give the Irish Bank Restructuring Corporation, which had taken over the bank, the right to redeem nonparticipating bonds at 1 cent on $€ 1,000$, effectively wiping out their value. The High Court deemed this oppressive and ruled for the fund challenging the transaction.

The judge appeared amenable to a softer version of exit consents, whereby nonparticipants are given value equivalent to that received by the participants. However, when the worst possible outcome for nonparticipation is getting the same terms as everyone else, the urgency of signing up for an exchange goes away.

worthless instrument. However, since the advent of CACs on a mass scale in 2003, important nonfinancial terms in sovereign bonds have generally migrated to the list of reserve matters that require supermajority amendment, along with financial terms. This means that blocking the removal of a pari passu clause through exit consents is now just as easy as blocking the change in the payment terms itself. In addition, a U.K. court's decision in 2012 potentially limits the use of exit consents in distressed exchanges (box 2).

This seems to leave only one approach to ad hoc debt restructuring that could avoid the new threat of third-part enforcement, albeit at a much higher risk of litigation by "mainstream" creditors. Rather than offering a debt exchange that would create incentives to hold out, debtors could simply default "ratably" on all creditors at once. For example, a debtor could announce a new payment stream equivalent to that which it would have offered in the form of a new debt preceding the New York decisions. By treating all creditors the same, this approach would sidestep the possibility of enforcement. But this comes at a high price, given that the debtor would plunge into a torrent of litigation and likely forgo any hope of a fresh start.

\section{Pari Passu Is Not All}

Even in the absence of legal and institutional reforms along the lines proposed in this report, the pari passu problem may well recede over the next decade or so (though only very gradually, given the typical maturities of sovereign bonds). Sovereigns and their creditors, including major trade associations, have adapted their contracts in response to litigation and other restructuring developments. There is some evidence that this adaptation process has already begun in response to New York court rulings. Hence, although recent legal developments are likely to pose problems for debt restructuring in the short and medium terms, their effect is likely to diminish over time. 
However, this fact obscures a more significant structural problem, of which the pari passu saga is a symptom. With no clear path to enforcement or a fresh start, both sides in the sovereign debt restructuring game try to leverage contract provisions to win a given round. As the pari passu clause is gradually replaced, another technique will likely surface as a platform for recovery. All it will take is for one adventurous (or frustrated) court to interpret a contract term in an unconventional way for a brief period of time. In the next round, sovereigns might respond with more aggressive restructuring techniques. The same contractual flexibility that produces ingenious restructuring techniques lends itself to ingenious enforcement techniques, and so on.

Put differently, contracts as interpreted by judges have proven inadequate to mediate the tension be- tween the lack of enforcement and the impossibility of discharge in sovereign debt. To the extent that contracts improve over time and leave less room for interpretation, this problem may recede. That said, experience suggests that this is at best an uncertain process that will take several decades-adaptation is a long and winding road littered with institutional problems, and is not at all certain to address interpretive shocks or result in more perfect contracts (Gulati and Scott 2013). Hence, a solution that is both durable and takes effects reasonably quickly will require policy action - whether to improve contracts in a more radical and coordinated fashion than adaptation would produce on its own, or to create statutory solutions that can complement existing contracts. 


\section{снаттев 4: Euro Area Issues}

\section{Euro Pathologies}

Although some of the pathologies related to overborrowing and delayed restructuring that were described in chapter 2 can be illustrated using euro area experiences (particularly the case of Greece), they have been well known in emerging market settings for some time. This said, the euro area does appear to be special in ways implying that the general case for an overhaul of the rules governing debt restructuring-and particularly for a treaty-based mechanism-may apply with special force. In particular, the euro area embodies two structural features that exacerbate both the ex-ante pathologies described in chapter 2 and the difficulties of managing debt crises ex post, particularly in combination.

First, a debt crisis afflicting one country in the euro area constitutes a common problem for the entire currency area, to a degree that dwarfs crisis-related spillovers anywhere else in the world. This is partly the result of close trade and financial linkagesincluding through holdings of sovereign debt by banking groups and other institutional investors with cross-border presence. However, economic linkages are also very high-for example, between the U.S. and Canada, between the U.K. and some euro area countries, and between Germany and Switzerland-without tying these countries to- gether in quite the same way as within the euro area. Apart from a shared and often difficult history that rarely leaves room for indifference, what sets the euro area apart from other highly integrated areas is that the common currency itself constitutes a powerful channel that links economic outcomes among its members. This is partly because the policies of the European Central Bank (ECB) affect the entire currency area, but most of all because of the threat of a collapse of the common currency, and the associated disruptions that this would create across the currency area. As a result, a disorderly default in one part of the currency union could have massive implications for its other members-even members whose direct exposures to the afflicted country are not very high.

Second, euro area countries have fewer policy instruments for dealing with high debt. In particular, unless the euro area as a whole has a debt problem that is symmetrical across most members of the currency union, the area's member countries cannot count on devaluation or accommodative monetary policy to offset the contractionary impact of fiscal adjustment. As a result, debt reduction efforts are economically and socially more costly for given debt and deficit levels, and debt sustainability problems arise at lower levels of debt than in comparable countries with their own monetary authorities. 
Note that the second problem-a lack of monetary policy instruments to help deal with high debt-is by no means unique to the euro area. It is, in fact, almost identical to the standard problem arising from foreign currency borrowing that has afflicted emerging market economies for many decades. Just as in the euro area, the presence of foreign currency debt renders standard monetary policy instruments essentially useless in a crisis, and implies that crises can be self-fulfilling. ${ }^{23}$ What is special about the euro area, however, is the combination of a lack of instruments to deal with debt crises in individual countries and the fact that, if these debt crises spin out of control, there could be dire consequences for the entire common currency area. As a result, the need both for a regime that prevents the emergence of debt problems and for additional policy instruments to handle debt crises when they do occur has been much more urgent in the euro area than elsewhere.

So far, these "additional policy instruments" have consisted mainly in the combination of fiscal adjustment and large-scale, conditional official support (either through the European Financial Stability Facility / ESM or the ECB's "Outright Monetary Transactions" program). Though these forms of support can stop self-fulfilling debt crises when debt is in principle sustainable, by definition they do not work in unsustainable debt cases. But because official support and fiscal adjustment are the only instruments on the table, the existing regime creates an incentive to misdiagnose debt problems-declaring the unsustainable sustainableand to stigmatize those that disagree. Before the Greek debt restructuring finally became the official policy of the European Union in the second half of 2011, even the discussion of debt restructuring in Europe was effectively branded as un-European by influential policymakers. ${ }^{24}$ In turn, this can result in adjustment burdens that ultimately prove unfeasible, but usually not until they have caused great social and political harm.
At the same time, large-scale crisis lending can give rise to moral hazard, at two levels: at the expense of the European taxpayer if official loans themselves have to be written down-as seems likely when lending occurs in unsustainable debt cases-but also at the expense of the domestic taxpayer, who is required to repay official loans that are being used to service debts to private creditors. The consequences are underpricing of debt and overborrowing, particularly in countries with weaker institutions and political systems that are not fully responsive to taxpayer interests.

Fortunately, the euro area is special not only with respect to its problems in preventing and containing debt crises but also in its potential to establish common institutions or legal frameworks to create new solutions. Euro area members are of course also members of the EU, which has had a long, and for the most part successful, record of cooperating through supranational legal frameworks and institutions. Furthermore, the euro area has one particular specific institution-the ESM, created by treaty in 2012-that could be easily adapted to embed a treaty-based debt restructuring regime. The next chapter hence explores the possibility of an amendment of the ESM treaty that would attempt to impart incentives for better debt management ex ante, bestow legitimacy on debt restructuring when this is in the common interest, and deal with the legal obstacles to debt restructurings posed by holdouts.

Before going down this route, however, it is necessary to address four possible objections, all of which are specific to the euro area context:

- First, does the diagnosis change if one takes into account the nexus between public and private debt-including overlending by banks? In light of this nexus, might the creation of a euro area-based Banking

\footnotetext{
${ }^{23}$ See Jeanne and Zettelmeyer (2003), and the references therein.

${ }^{24}$ Nicolas Sarkozy, "We Will Show That Europeans Pay Their Debts," International Financing Review, December 10, 2011. Similar statements were made by ECB officials, particularly Lorenzo Bini Smaghi; see "Private Sector Involvement: From (Good) Theory to (Bad) Practice," Berlin, June 6, 2011, http://www.ecb.int/press/key/date/2011/html/sp110606.en.html.
} 
Union-with a common fiscal backstopbe sufficient to deal with sovereign debt problems in Europe?

- Second, was the Greek debt restructuring a game-changer in the sense that it demonstrated the feasibility of orderly debt restructuring in the euro area? In light of this success, does the euro area still need a more formal restructuring regime? Or does the Greek restructuring solve the problem both ex ante, by sending a warning to future reckless sovereign borrowers and lenders, and ex post, by creating a template for future restructurings in the euro area, should they become necessary?

- Third, could the problem be solved by the "aggregated" collective action clauses that, since early 2013, have begun to be incorporated into the newly issued sovereign bonds of all euro area members? Do these CACs already constitute a restructuring regime of sorts that might obviate the need for a more heavy-handed alternative?

- Fourth and finally, could the recent reforms of the European fiscal framework make a debt restructuring regime redundant? Should not the new rules and strengthened oversight suffice to ensure fiscal discipline and to curb moral hazard? Also, ESM funding is already conditional on fulfilling the fiscal targets, so why is there a need to go any further?

\section{Banking Union and the Nexus between Private and Public Debt}

It has often been pointed out that the euro area crisis was primarily caused by capital flows and bank credit directed mainly at private rather than public borrowers, together with the higher risk premia and break- down in interbank lending triggered by the subprime crisis in the United States. ${ }^{25}$ With few exceptionschiefly, the problems of Greece-sovereign debt problems in the euro area have been a consequence, rather than the cause, of this broader crisis.

In the context of the discussion so far, this raises several questions. If the main problem in Europe was (and to some extent still is) privately held debt, does the emphasis on sovereign debt restructuring miss the point? Even worse, might a sovereign debt restructuring regime be rendered ineffectual by the tight link between private and public debt? And to the extent that this link is at the core of the sovereign debt problem in Europe, would it not be addressed by the Banking Union that Europe has begun to build, obviating the need for a sovereign restructuring regime?

The first and most obvious answer to these points is that although public and private debt are related for the usual reasons-because private overborrowing can become public in a banking crisis, and but also because public overborrowing can crowd out private borrowing-they are still separate problems in the sense that they are driven by distinct moral hazard problems, each of which would continue to pose a threat if the other were eliminated. In particular, even if new financial sector institutions and macroprudential policies were to eliminate any chance of unsalutary private credit booms in Europe, a potential public overborrowing problem would remain, for the reasons described in chapter 2, and would be particularly important to address in the euro area. For the reasons described earlier in this chapter-the lack of country-level monetary policy instruments, larger mutual costs of debt crises, and moral hazardprudent sovereign debt levels in a currency union of closely integrated economies should probably be lower than elsewhere. This may require a supranational debt restructuring framework to both set

\footnotetext{
${ }^{25}$ See, e.g., Lane (2012); Lane and Pels (2012); Shambaugh (2012); Sinn and Wollmershäuser (2012); and Hughes Hallett and Martinez Oliva
} (2013). 
the right incentives and deal with large accidents. The presence of such a framework does not, of course, obviate the need to also improve financial sector supervision and resolution, both because of the disruptiveness of crises caused by private credit booms and to prevent private debt from becoming a public liability.

Second, while sovereign bankruptcy should obviously not be the first line of defense against banking crises, it can help, even with private borrowing problems. Ex post, it would provide a framework for the restructuring of public liabilities regardless of their origin. To the extent that debt markets believe that private liabilities could at some point become public, this should create additional incentives-via the national treasury-to prevent overborrowing. In a country with rapidly rising private debt and a strong chance that this debt will become public, but without any chance of sovereign debt restructuring, sovereign borrowing will remain cheap. In the same world with a chance of debt restructuring, unsustainable private borrowing should at some point begin to affect sovereign risk premia, even if sovereign debt remains low. Because it gives the fiscal authorities a wake-up call, this is a good thing.

Third, euro area-based Banking Union, a fiscal backstop and a sovereign debt restructuring regime should be viewed as-indeed, a sovereign debt restructuring regime is likely necessary for the proper function of the Banking Union. Based on the arguments that were made at the beginning of this chapter, one can in principle imagine two alternative, internally consistent institutional arrangements for the euro area that recognize the links between public and private debt. First, one in which both supervision and resolution remain national responsibilities, and in which a sovereign debt restructuring regime deals with national debt shocks-regardless of whether their origin lies in the public or private sector. Second, one in which both supervision and resolution are joint, and there is both a common backstop and a sovereign debt restructuring regime.

In a financial area with cross-border banking, the latter is preferable because it internalizes the multicountry effects both of banking in normal times and of bank resolutions. But it will work only if the authorities whose decisions ultimately influence the quality of bank assets have the right incentives. With major decision areas-for example, influencing housing markets-remaining at the national level even in a perfect Banking Union, this requires that national authorities retain "skin in the game," in the sense that national fiscal backstops, if required in the resolution process, are tapped before common euro area-level backstops. This, in turn, requires that meaningful fiscal buffers exist at the level of all euro area countries, which in turn require creating incentives against overborrowing through standard fiscal channels-one of the purposes of orderly sovereign restructuring. At the same time, because significant decisionmaking authority in the Banking Union will be centralized, the possibility of sovereign restructuring does not obviate the need for a common fiscal backstop. If decisionmaking authority over national financial systems is explicitly or implicitly shared, so, too, must fiscal responsibility. ${ }^{27}$

\section{The Greek Debt Restructuring-a Template?}

Notwithstanding its restructuring-unfriendly conditions, the euro area recently pulled off the largest debt restructuring in history: the 2012 Greek bond exchange, which was successful in the sense

\footnotetext{
${ }^{26}$ While it is beyond the scope of this report to propose how these mutual responsibilities should be calibrated, the general principle is clear: There must be a relation between national responsibility for preventing financial sector accidents and the contribution toward the resolution of a financial sector crisis that would be covered from national fiscal sources before use of ESM resources. The latter could be set as a share of national GDP (e.g., 20 percent, set uniformly across euro zone members on the assumption that national financial sector responsibilities comprise similar functions in all countries). Should this exceed national fiscal capacity, sovereign and banking system assets would have to be restructured jointly.
} 
of being orderly; in achieving high creditor participation (97 percent); and in resulting in large debt relief, on the order of 50 percent of GDP. ${ }^{27}$ Was the Greek restructuring a game-changer that it could by itself usher in an era when unsustainable debt cases in Europe are dealt with through orderly restructuring? Even ignoring the fact that European policymakers have consistently emphasized that the Greek case would remain unique and not set any precedent for the handling of other high-debt cases, there are reasons to doubt this.

First, the Greek debt restructuring was quick and achieved high creditor participation for mainly one reason: 93 percent of Greek bonds were governed by local (Greek) law. This permitted the Greek Parliament to "retrofit" a collective action mechanism on the local law debt stock that operated to sweep potential holdouts into the deal, and also gave Greece scope to offer creditors extra incentives that reduced the appeal of holding out, namely, an upgrade in governing law. However, not every euro area country enjoys the local law advantage that Greece did. This applies particularly to some of the smaller euro area countries and borrowings by subsovereign entities. Cyprus is a case in point. During its recent bail-in of investors, it imposed the bulk of the pain on its bank depositors, while holders of its foreign-law-governed bonds (a substantial portion of its debt stock) have been paid in full and on time.

Second, the Greek approach to restructuring required large volumes of official financing, as the exchange offer included an exceptionally high "cash sweetener" to incentivize participation. ${ }^{28}$ This is unlikely to be repeated. Rescue money is becoming scarce in the euro area, both because of public and political opposition to further bailouts and be- cause the pool of available resources is shrinking, as demand continues to increase and the potential roles of the European Financial Stability Facility / ESM are being expanded (most recently to direct recapitalization of banks).

Third, the Greek restructuring gave potential holdouts an easy pass-both by avoiding virtually any threats directed at holdouts ex ante and by repaying them in full ex post. This creates a precedent that will likely embolden holdouts in future restructurings.

Fourth, a little-noticed aspect of the Greek restructuring is that it attempted to restructure not only its sovereign bonds but also some of its sovereign guarantees. Sovereign guarantees can quickly become direct sovereign obligations when a country hits a crisis (particularly if the guarantees were being used to prop up already-weak domestic institutions that become weaker still when the crisis hits). As a historical matter, sovereign guarantees have tended not to pose a major problem in restructurings because distressed nations do not usually have too many of them. The crisis in the euro area, however, has been different. Many of its members have issued large volumes of sovereign guarantees in the period since 2008, and are continuing to do so. This means that when the next euro area restructuring comes along, the guarantees will also need to be tackled, without a clear playbook on how to do so (Buchheit and Gulati 2013).

Finally, a large fraction of the bonds issued by the weaker euro area sovereigns have recently been moving out of the hands of foreign investors and into the hands of local banks and other domestic institutions (Brutti and Sauré 2013). That means that any significant restructuring of the govern-

\footnotetext{
${ }^{27}$ This is not to say that it was perfect. It came far too late, created large risks for the European official creditors, left money on the table, and ultimately was not deep enough to restore Greece to sustainability. Furthermore, it created a bad precedent in its exceedingly generous treatment of holdouts. For the details, see Zettelmeyer et al. (2012).

${ }^{28}$ Quasi-cash payouts (in the form of short-term European Financial Stability Facility bills) made up about two-thirds of the value of the package of new instruments offered to Greece's private creditors. This high reliance on cash seems to have been unprecedented in the history of sovereign debt restructuring. See Zettelmeyer et al. (2012) for details.
} 
ment's debt may cause a domestic banking crisis. Of course, this is the reason why the migration of sovereign debt to domestic holders, and banks in particular, could be happening. Domestic banks are relatively immune from restructurings because they expect to be recapitalized, for financial stability reasons, if their losses from domestic sovereign bond holdings are sufficiently high. Indeed, if the holdings of the banking system as a whole are high enough, the restructuring will likely not happen at all (see Broner et al. 2010).

Hence, while the Greek debt restructuring approach was successful in Greece and can be useful in specific cases, it falls short of providing a template that could be a permanent fixture of the European financial architecture. Indeed, its success was partly due to strategies-including the large-scale use of cash incentives, and the generous treatment of holdouts-that may make future restructurings more difficult.

\section{Are the New Euro-CACs the Solution?}

Since January 2013, newly issued European sovereign bonds have begun to incorporate collective action clauses. The trigger for a debt restructuring (both sovereign, as in the case of Greece, and private, as in Cyprus) is based on an ex-post debt sustainability assessment by the Troika i.e., the European Commission, the ECB and the IMF). The intention of these clauses is to facilitate debt restructuring when appropriate and improve incentives ex ante. But unfortunately, the new regime is unlikely to be sufficient, for two main reasons:

- Although euro-CACs may help with the ex-post debt restructuring, they are no panacea, as they need to be voted on bond by bond (see Gelpern and Gulati 2013).
It is telling that distressed debt investors explicitly targeted Greek bonds with U.K.-law CACs: These holdout investors succeeded by purchasing blocking minorities in individual bond series, which could not be offset by pro-restructuring majorities elsewhere. Though euro area CACs contain an "aggregation feature" that allows changes at the individual bond level to be decided with a lower majority if enough investors across all bonds vote for a restructuring, this feature is much weaker than the mechanism for aggregating bondholder votes across all domestic law bonds that was used in Greece. ${ }^{29}$ Furthermore, euro-CACs do not deal with the vast existing stock of European sovereign debt. Some of this was issued under domestic law so that CACs can be "retrofitted" if necessary, but a significant amount of it is not.

- Case-by-case sustainability analyses are part of the negotiation, and not predictable. As such, they do not help with the ex-ante distortions, particularly when declaring a country insolvent remains an unattractive option in light of the restructuring barriers that remain even with euro-CACs.

A possible solution might be to reform the newly introduced euro-CACs in a way that they allow aggregation across bond series, without bond-bybond voting. However, even if this happened, it will take another 5 to 10 years until they will be contained in the majority of euro area sovereign bonds. Until then, there will be a mixed regime of pre-2013 bonds (mostly without CACs) and post2013 bonds (with euro-CACs). And even in 10 years, it is not clear whether euro-CACs would ever be used, as the decision to withhold ESM support and encourage countries to restructure remains

\footnotetext{
${ }^{29}$ The aggregate voting threshold is higher than in the Greek "retrofit" CAC (75 rather than 66.67 percent). Furthermore, euro-CACs require at least a 66.67 percent vote in each individual bond issuance, while in Greece it was sufficient to reach this threshold in aggregate.
} 
discretionary, and may or may not be optimal ex post. This is far from the regime that Europe needs to both succeed in future restructurings and create good incentives ex ante.

\section{Is a Debt Restructuring Regime Redundant?}

After the obvious failure of the fiscal (and macroeconomic) framework, the EU and the euro area embarked on a large-scale effort to strengthen its governance. In particular, the so-called six-pack (i.e., six regulations designed to strengthen fiscal discipline and macroeconomic surveillance) was adopted by all EU member states in 2011; an intergovernmental treaty (Treaty on Stability, Coordination, and Governance), also called the "fiscal compact," was signed by $25 \mathrm{EU}$ member states in 2012; and two further regulations (the "two-pack") entered into force in the countries of the euro area in $2013 .{ }^{30}$

Together, these new regulations have substantially changed the governance of the euro area. On the fiscal side, for instance, excessive deficit procedures may now be launched on the basis of a debt ratio above 60 percent of GDP that does not diminish sufficiently rapidly. The debt reduction path must follow a numerical benchmark, and progressive financial sanctions kick in at earlier stages than previously. The fiscal compact further reinforces fiscal targets, mandates their implementation in national law-preferably at the constitutional level-and gives the European Court of Justice the right to monitor the implementation of the law and impose sanction for noncompliance. Furthermore, the ESM is barred from lending to countries that violate the fiscal compact, giving countries a further incentive to keep their fiscal house in order; by the same token, the presence of the ESM should not cause incentives to engage in fiscal profligacy.
Finally, the two-pack introduces EU-level budget monitoring and coordination through a common budgetary time line and procedures. For the euro area countries, the commission will now examine and give an opinion on the draft budget, and may ask for the submission of a revised plan.

With all these new instruments and powers, one could conclude that the euro area is already sufficiently equipped to ensure fiscal discipline and prevent repeated debt crisis. However, this conclusion would be premature, for two reasons.

First, although the fiscal compact mandates fiscal rectitude and prohibits the ESM from helping countries that do not comply (after an adjustment period, agreed on country by country), it does not provide any alternative instruments for dealing with a debt crisis. This means that if a country does not follow the rules and a crisis does arise, European policymakers will again be caught between a rock and a hard place. If they reject a country's call for support, they will likely force it into a debt restructuring, but without tools that legitimize the restructuring and ensure its orderliness. This may again lead to pressures to make an exception and allow the ESM to lend to the country after allvery similar to the pressures that led the IMF, for example, to change its exceptional access criteria in order to enable it to lend to Greece.

Second, the most of the new rules aim at improving discipline in fiscal terms. Although the six-pack also introduces a new macroeconomic imbalance procedure, which together with the European Systemic Risk Board is to monitor and prevent excessive risk taking in the financial and in the private sector. However, this may not be sufficient to rule out situations where a country's debt becomes unsustainable because of the accumulation or "discovery" of quasi-fiscal liabilities which become fiscal in a crisis.

\footnotetext{
${ }^{30}$ See European Commission, "Six-Pack? Two-Pack? Fiscal Compact? A Short Guide to the New EU Fiscal Governance," http://ec.europa. eu/economy finance/articles/governance/2012-03-14 six pack en.htm. The ESM treaty and the fiscal compact ("Treaty on Stability, Coordination, and Governance") are also available on the European Commission's Web site.
} 
Building a debt restructuring framework for Europe on top of its existing fiscal governance would at worst be costless and at best essential. If the new rules do indeed ensure that the debt of all euro area members declines to below 60 percent of GDP and remains there, the restructuring regime would serve as a second line of defense that may never be breached. The probability of a debt restructuring in such a case would be minimal, and so would be any impact of a debt restructuring regime on borrowing costs. If, conversely, the new rules do not work as intended-as may be the case if euro area countries are not able or willing to live up to their new commitments, or if their debts become unsustainable for reasons outside the new fiscal rules-a debt restructuring regime would harness market discipline in normal times and provide a safety valve in crisis times. 


\section{снатев 5: Policy Proposals for the Euro Area and Beyond}

\section{What Should A Reform Achieve?}

Ideally, to meet the objectives outlined in the previous sections, a debt restructuring regime would meet four conditions:

- Address the ex-ante problem of mispricing of risk and overborrowing through a predictable regime that sets transparent criteria for sovereign restructuring and limits the scope of official sector involvement;

- Make sovereign debt restructuring in unsustainable debt cases politically and legally legitimate-removing the stigma that contributed to the misdiagnosis of the Greek case, for example;

- Provide a crisis management framework that reduces the economic cost and systemic financial risks of debt restructuring to manageable levels, both in the country that restructures and in countries with exposures to the restructuring country; and

- Deal with the holdout problem ex post.

The first three conditions are as critical (or more so) as the fourth one. Unless they are met, debtor countries will continue to be subject to creditor runs. In the case of the euro area, even a legally coherent statutory mechanism along the lines of the IMF's 2003 SDRM proposal would not work, simply because the debtor countries would not invoke it because of fear of stigma and economic collapse; and the other euro area countries, the ECB and other EU authorities would oppose its use for fear of contagion and legal challenge.

Given the plethora of sovereign debt problems presented in chapters 2, 3 and 4, the first and best approach to addressing these problems would presumably be fully fledged international sovereign insolvency-cum-crisis management regime that is capable of dealing with many inefficiencies at once. But such a regime is practically and politically unfeasible. In light of this, we structure the remainder of the discussion as follows:

- At the global level, the main difficulty is to obtain a critical level of political support for institutional or legal reform that would have consequences in most if not all major international jurisdictions. In light of this, we review several reform options that are increasingly more ambitious and deliver better solutions at the price of requiring a greater degree of consensus across governments.

- In the euro area, creating or modifying common institutions is far less taboo. 
Indeed, a treaty-based sovereign insolvency regime in Europe would pale in comparison with some of the dramatic institutional changes in the euro area that have already been made or are in the process of being negotiated-starting, of course, with the common currency itself, and more recently comprising the creation of the ESM, the fiscal compact, and the Banking Union. The challenge lies in the details of how to design such a regime, and particularly in how to manage the transition from the present crisis, when expectations of debt restructuring could easily turn out to be self-fulfilling, including in countries where it may be better to reduce debt levels through a combination of adjustment and economic recovery rather than through restructuring.

\section{International Solutions}

At the international level, we distinguish three reform options.

- The first two are aimed exclusively at the holdout problem. We distinguish between a purely contractual approach (Option 1), and limited statutory reform (Option 2). Neither is likely to have a major impact on incentives to overborrow or on the "too little too late" problem with regard to debt restructuring.

- The third alternative is somewhat more ambitious, and would involve the IMF. It would both address the holdout problem and could have a limited impact on incentives more broadly-particularly the problem that countries tend to restructure too little.

\section{Getting Serious about Aggregation}

As briefly described in the previous chapter, euro area nations have introduced an aggregation feature in all new sovereign bond contracts that would make it more difficult for holdouts to obtain blocking majorities in individual bonds. Specifically, the supermajority threshold that needs to be obtained in order to restructure individual bonds is lower if there is a large supermajority across all bonds that favors the restructuring.

In the post-Argentina/NML world, these aggregation features may not go nearly far enough, particularly in a global context. Individual bond series of smaller countries can be so small (and cheap, in a distressed debt case) to be easily purchased by prospective holdouts in their entirety. To deal with these holdouts, modest trade-offs between supermajorities at the aggregate and the individual bond levels are unlikely to be sufficient. Instead, what might be needed is an aggregation mechanism along the lines used in the Greek restructuring of 2012, which allowed for the restructuring of individual bonds issued under Greek law even against the wishes of the majority of holders of that bond, provided that the restructuring was backed by a supermajority of bondholders across all bonds. ${ }^{31}$ In the case of Greece, what mattered was only the aggregate support for the proposed restructuring; that is, the wishes of the holders of individual Greek law bond series were not even considered. In the context of the Greek restructuring offer, which went out of its way to avoid discriminating against bondholders that chose to vote against the proposed restructuring, ${ }^{32}$ this was both effective and arguably fair.

In a more general setting, one needs to be careful to avoid a contractual change that could enable the expropriation of a minority of creditors-that is,

\footnotetext{
${ }^{31}$ Namely, 66.67 percent of face value, provided bondholders representing a least 50 percent of face value participated in the vote.

${ }^{32}$ For the details, see Zettelmeyer, Trebesch, and Gulati (2013).
} 
a situation where a supermajority of creditors attempts to extract a disproportionate haircut from a minority (e.g., the creditors in a small bond issue). To avoid this, two avenues are conceivable:

- The conventional approach is to seek consent at both the aggregate level and, for each individual bond series, albeit with lower majority thresholds, at the individual series level. As argued above, the problem with this approach is that it allows holdouts to concentrate their holdings in some of the smaller bond issues, where they can block at least a portion of the restructuring.

- A better approach would be to require a separate "per series" vote only in cases where the terms of the proposed restructuring are not uniformly applicable across all the series of bonds. This "uniformly applicable" requirement should prevent an issuer from colluding with the holders of certain series to discriminate against others. $^{33}$

Getting serious about aggregation in the manner described in the second approach would be a significant departure from existing practice in the drafting of bond contracts. Experience tells us that coordinating marketwide changes in contracting practices can both be difficult and slow, even where there is widespread agreement regarding the welfare benefits of such a move. For this reason, strong aggregation features are unlikely to come about spontaneously. If the shift to aggregation must occur quickly, there will probably need to be a significant dose of official sector encouragement, as there was with the CAC initiative in the New York law market in 2002-03. ${ }^{34}$ Even greater coordination would be needed to include aggregation features in the existing stock of bonds, because this would require debt exchanges of existing bond series against otherwise identical bonds with aggregation provisions.

\section{A Limited Statutory Reform}

As described in chapter 3, holdouts in Argentina's debt restructuring have found a way of inflicting major collateral damage by threatening the conduits of payments to creditors under performing debt contracts. Thus the attack targets trustees, payments and clearing systems around the world.

The countermeasure would be to adopt legislation immunizing all payment and clearing systems in large financial centers, much as Belgium immunized Euroclear from creditor injunctions in response to Elliott's lawsuit against Peru:

Any cash settlement account maintained with
the operator of a system or with a cash settlement
agent, as well as any cash transfer, through a Bel-
gian or foreign credit institution to be credited to
such cash settlement account, cannot be attached,
put under sequestration or otherwise blocked by
any means by a participant (other than the oper-
ator or the settlement agent), a counterpart or a
third party. (Euroclear translation of Belgian Act
of April 28, 1999, as amended by Act of Novem-
ber 19,2004)

It would be sufficient to coordinate and adopt substantively the same legislation for a handful of financial centers in which most sovereign bonds are issued and traded. Immunizing market infrastructure from holdouts would increase the attractiveness of financial centers adopting this measure, because it would reduce the likelihood of disruption from lawsuits against participants or beneficiaries. This limited reform might provide a global solution to the problem of holdouts emboldened by the prospects of third-party enforcement. But it would only serve to reestablish the balance of power that

\footnotetext{
33 "Uniformly applicable" does not necessarily mean that all bonds series would have to be transformed into an identical instrument or bundle of instruments. E.g., a uniform extension of the maturity of all series by five years, or a reduction of all coupons by 1 percentage point, or by 20 percent, would also constitute a "uniform applicable" change.

${ }^{34}$ For the details, see Gelpern and Gulati (2006); and Bradley and Gulati (2012).
} 
existed before NML v. Argentina. It would not address incentives to overborrow, to procrastinate and to restructure too little, too late.

This solution could be implemented through changes in the relevant law as of major financial centers. Presumably, such legislation would present a competitive advantage of the first moving financial center because it would attract trading and payment business to that location. However, for the same reason some coordination and harmonization of immunization policies may be desirable.

\section{An IMF-Based Sovereign Debt Adjustment Program}

The two proposals so far have the advantage that they do not create new international institutions (or change the rules of existing ones) or require new treaties or treaty changes. But by requiring less, they also achieve less. Because they focus only on the holdout problem, they would not address the incentives to overborrow and procrastinate that relate to the moral hazard caused by international bailouts, political economy and the other distortions discussed in chapter 2. Hence, they would not have much of an impact on strengthening incentives ex ante.

To make progress in this area-and to deal with the holdout problem at the same time-it is necessary to both make it more difficult for governments to postpone necessary debt restructurings by resorting to international official borrowing, and to make the restructuring process less risky and more predictable. At the international level, the only practical way of achieving that is through a modification of the way in which the IMF assists countries with debt burdens that run a significant risk of being unsustainable.
In principle, the IMF's internal rules forbid the Fund from lending to such countries even now. In practice, however, these rules were overruled or reinterpreted to enable the Fund to lend in cases such as Greece. Part of the reason for the pressure to do so is that international crisis lending, combined with domestic adjustment and reform, is currently "the only game in town" when the official community attempts to help countries in a debt crisis. The IMF can offer this traditional package, or offer nothing.

To address this problem, and to effectively give the IMF a second instrument for assisting high-debt countries, a dedicated IMF lending facility could be created, which we refer to as the Sovereign Debt Adjustment Facility (SDAF). ${ }^{35}$ It would serve two main-related-purposes: to create a stronger commitment device for the Fund not to be drawn into bailing out countries whose debts are likely unsustainable unless these countries also restructure; and to protect countries that undertake orderly restructurings in the context of the SDAF from holdouts.

Criteria. To qualify for IMF access under an SDAF, the country would need to be in a situation where debt sustainability is no longer assured without substantial debt relief. The Fund would have to establish criteria under which countries would be eligible for an SDAF in a similar fashion as the criteria that were established for qualification under the Heavily Indebted Poor Countries (HIPC) initiative. Like in the HIPC initiative, it will be necessary to have a multidimensional scheme (using a combination of debt-level and vulnerability indicators) - which would, however, be defined ex ante. Countries that fall under the criteria determined by this scheme would not have access to IMF crisis lending except under the SDAF.

\footnotetext{
${ }^{35}$ This section is draws on proposals by Broomfield and Buchheit (2013) and Panizza (2013).
} 
This would imply a shift from the status quo, where debt sustainability assessments are case by case and tend to be relevant only after the fact, that is, when the country has almost lost market access. The advantage of such an approach is that it would bind the IMF ex ante and would remove the process of establishing debt sustainability from the negotiation process, and would also avoid the somersaults that happened in the case of the Greece. The disadvantage, of course, is that it would not be easy to establish criteria for lending in debt adjustment and restructuring cases that applied across countries.

A variant that addresses the problem of defining ex-ante criteria that will "fit" all countries might work as follows. SDAF criteria would still be established, but instead of tying any IMF lending to a debt restructuring, they would trigger a twostep procedure. ${ }^{36}$ In the first step, a country would have the option of requesting a traditional adjustment program, on the condition of defining country-specific criteria that would, if they are triggered, prevent the Fund from extending further assistance without debt relief-which would be the second step. This proposal would address the presence of a "gray area" in which predefined criteria raise doubts about the lack of debt sustainability, but the country argues (and IMF staff might agree) that these criteria are too coarse and insufficiently country specific, and that adjustment could potentially rectify the situation without a debt restructuring. The essential difference between this variant of the SDAF and the status quo is that, under its current rules, once programs go off track the Fund has broad leeway to adjust conditionality and continue lending. Under an SDAF, this leeway would be restricted to support programs that embed a debt restructuring.

The trigger of the process would continue to be in the hands of the debtor country. The country would request an SDAF in the way in which it currently requests other forms of IMF support. If the Fund accepts the country's request, it would prepare a draft Debt Sustainability Analysis (DSA), which sets out the macroeconomic adjustments as well as the contributions expected from the debtors multilateral, bilateral and private creditors (in the twostep variant discussed above, this would become relevant in the second step). In preparing a DSA, the Fund would be guided by the principle of equitable burden sharing among all classes of creditors except for recognized exceptions such as multilateral financial institutions and, where appropriate, trade/supplier creditors, short-term treasury bill holders and similar categories.

The draft DSA would be discussed with the debtor countries' authorities and comments could also be invited from creditors, citizens of the debtor country and civil society groups. If an agreement were to be reached between the debtor country and the IMF, the process would proceed in a manner consistent with the final DSA.

Restructuring. The debtor country would approach each creditor group, creditor committee or similar body and seek debt relief consistent in a net present value sense with the assumptions of the final DSA. The draft DSA would be posted on a publicly available Web site, and interested parties (creditors, citizens of the debtor country and civil society groups) would be invited to comment. If thought appropriate, the staff of the IMF could invite interested parties to present their views in person.

Following discussions with each affected creditor class, the debtor country would formulate the terms of its restructuring proposal with each creditor group holding claims that would be eligible to participate in the restructuring (eligible claims). The IMF would review each of these proposals to ensure that it would be, in a net present value sense, not more burdensome to the creditor that shall be required by the assumptions of the DSA.

${ }^{36}$ See Panizza (2012). 
The restructuring could be subject to supermajority creditor control by requiring the support of holders of at least 75 percent of the affected debt instruments.

"Defanging" Holdouts. Holdouts could be dealt with by immunizing, in all IMF member countries, the assets and revenue streams of the debtor country against attachment by the holder of a debt instrument that was invited to participate in a Fund-approved SDAF but declined to do so. This would be similar to the limited reform discussed in the last section in the sense that it would immunize the payment streams rather than limiting creditor rights directly. It would essentially simply add a new category to the immunities that most countries already recognize for foreign state property.

The reform could be implemented through a change in the Articles of Agreement of the IMF:

Article VIII 2 (a) of the IMFs Articles of Agreement could be amended by adding the following text:

"Any such restrictions imposed by a member in accordance with a Sovereign Debt Adjustment Program (as defined below) approved by the Fund shall for the purposes of this Article VIII 2(a), be deemed approved by the Fund. The assets and revenue streams of a member that has implemented a Sovereign Debt Adjustment Program approved by the Fund shall not be subject to any form of attachment garnishment, execution, injunctive relief or similar form of judicial process in the territories of any member in connection with an Eligible Claim Contract (defined below) for which the holder elects not to participate in that Sovereign Debt Restructuring Program.

"Sovereign Debt Adjustment Program," with reference to a class of creditors, means a debt adjustment program of a member that (i) is designed and implemented in a manner consistent with the Executive Board's decision taken at its meeting on 2014 ("Fund Policy with Respect to Members' Debt Restructuring Initiatives"), as that Policy may be amended or supplemented by the Executive Board from time to time and (ii) in which the holders of at least 75\% (measured by principal amount) of the Eligible Claim Contracts of that class have elected to participate. ("Eligible Claim Contracts" means contracts relating to debt instruments that are eligible to participate in a Sovereign Debt Adjustment Program approved by the Fund.)

The SDAF has some commonalities with the IMF's 2003 SDRM proposal, which also attempted to find a way of dealing with holdouts with the consent of a supermajority of creditors. There are two main differences:

- From a legal perspective, the SDAF would be much less intrusive than the SDRM proposed by the IMF in 2002-3. Unlike the SDRM, there would not be no automatic stay of litigation; no tribunal to hear disputes between the debtor and its creditors; and no mechanism for binding all creditors to the will of the supermajority. Holdouts would retain their claims, but could not expect to satisfy them by attempting (through judicial mechanisms) to seize the property of the debtor state held in the territory of a member.

- From an economic perspective, the main emphasis of the SDAF, unlike the SDRM, would be to establish a commitment device that would preclude the Fund from financing countries with doubtful debt sustainability. In its two-step variant, the SDAF would essentially constitute a structured learning process, which, in the first step, would give the benefit of the doubt to traditional adjustment, but where debt restructuring would become a binding requirement after an initial adjustment attempt failed.

\section{A European Solution}

As discussed in the previous section, a sovereign debt resolution regime that deals with both 
ex-ante and ex-post distortions is both more important and more realistic for the euro area than a comprehensive solution may be at the global level. Moreover, it could serve as a benchmark for any future global approaches. One advantage of the euro area is that there already exists a fiscal framework with debt thresholds that define fiscal solidity, to which all member countries have made a commitment. A European Sovereign Debt Restructuring Regime (ESDRR) needs to tie into this framework. Furthermore, for reasons of legitimacy and to be able to manage the collateral damage of debt restructuring, an ESDRR would need to be incorporated into the broader European crisis response framework.

\section{A European Sovereign Debt Restructuring Regime for the Long Run}

It is important to stress that our proposal for an ESDRR is not meant as to remedy the ongoing sovereign crisis. The ESDRR is a regime for the long run; its main purpose is to set incentives against excessive public (and indirectly also private) debt accumulation. To address the problems of the present debt overhang, creative and more flexible solutions will be needed (although such solutions could borrow our proposal's approach to the expost problem-that is, shielding sovereigns from holdouts if additional debt restructurings were to become necessary). The special difficulty in marrying the short and the long run is that incentives for adjustment now and prevention thereafter need to be aligned. Here, we present a European Debt Redemption Pact as a proposal that addresses the short-run problems and could serve as a bridge to the long-run ESDRR described here.
The proposed regime deals with two problems:

1. The ex-ante problem-by conditioning official lending on a restructuring regime and by designing the "when, how and how much" debt restructuring that is to be expected; and

2. The ex-post problem of immunizing the restructuring against holdouts.

The Vehicle. ${ }^{37}$ The ESDRR would be based on the European Stability Mechanism and take the form of a change in the ESM treaty to the effect of (1) conditioning ESM lending to certain debt thresholds and (2) preventing holdouts in ESM-sanctioned debt restructurings from enforcing their claims through European courts. At the same time, both the restructuring country and "innocent bystanders" would need to have access to ESM lending to deal with the fallout of a restructuring.

\section{Conditioning ESM Lending on Debt Thresholds}

As noted above, the euro area already has a fiscal framework embodying a definition of fiscal solidity, which revolves around the debt level of 60 percent. Our regime ties into this framework by using the 60 percent level as the threshold for conditioning official crisis lending by the ESM. ${ }^{38}$ At debt levels below 60 percent, ESM lending would be largely unconditional. At 60 percent plus $x$ (i.e., the upper threshold), ESM lending would be conditional on debt restructuring. In the intermediate space (between 60 percent and the upper threshold), the status quo regime of "constructive ambiguity" or "restructure only if absolutely needed" would remain. The effect would be to limit the range within

\footnotetext{
${ }^{37}$ This section is based on Buchheit, Gulati, and Tirado (2012); Weder di Mauro and Zettelmeyer (2010); and German Council of Economic Experts (2012).

${ }^{38} \mathrm{~A}$ related proposal that uses the 60 percent threshold (without a buffer zone) is the blue/red bold proposal by von Weiszäcker and Delpla (2010): Financing above 60 percent debt (with red bond) would be at risk of restructuring, whereas below 60 percent a joint and mutual guarantee would make restructuring highly unlikely.
} 
which the official sector is incentivized in order to gamble for resurrection and create moral hazard on the side of private creditors, but at the same time provide enough flexibility to accommodate large economic shocks.

Of course, there are several potential problems in using a particular debt threshold to define the restructuring regime:

- A debt threshold is an imperfect measure of solvency. It could lead to errors on both sides: Debts might be unsustainable even though the threshold is not reached, and some countries' debts might be sustainable even though they exceed the threshold. From the point of view of minimizing such errors, it would be better to opt either for country-specific debt limits or for much more complex rules that take into account off-balance-sheet items, considerations regarding the denominator (GDP vs. gross national product - the latter is 20 percent lower in Ireland than the former), the net international investment position, growth prospects due to demography and structural factors and, last but not least, political ability and a willingness to tax.

- A further consideration is that simple rules may not help credibility, if they turn out to be so inefficient ex post that the political system will find a way around them. The debt and deficit limits embedded in the Maastricht Treaty are a case in point. Furthermore, as in all cases when numbers become targets, conditioning on debt thresholds may create incentives to manipulate these statistics ("Goodhart's Law").

- Finally, tying officially sanctioned debt restructuring to just one solvency measure-a debt threshold-might distort country policies in ways that create vulnerabilities through other channels. In particular, it might create incentives to reduce debt costs through reliance on relatively cheap short-term financing-particularly when debt limits approach the upper threshold. This would be akin to gambling for redemption, encouraged by the fact that if excessively short-term debt were to trigger a liquidity crisis, the EMS would be there to help without necessarily requiring a debt restructuring-so long as total debt was below the threshold.

Although these are important concerns, we believe that they are either mitigated by the European situation or can be addressed with the proposed framework, as follows.

First, country-specific debt limits or complex solvency formulas are not desirable, for a number of reasons. The more complex the formula, the harder it would be to agree ex ante, and the greater the scope for manipulation ex post, undermining its credibility. Country-specific debt limits, conversely-for example, higher limits for countries that are deemed to have better institutions or more flexible economies, or possibly have historically shouldered larger debts-would not be accepted in Europe on equal treatment grounds and would be inconsistent with the logic of euro area membership, which carries the assumption of and commitment to convergence. Therefore, the economic parameters and fiscal threshold should be the same for all countries in the long-run equilibrium.

This leaves the euro area with a simple choice: to adopt simple ex-ante rules that constrain discretion when structuring ESM-led rescues, or to adopt no rules. Given the biases that currently exist against any form of debt restructuring (see chapter 4), pure discretion would lead to bigger errors than simple rules. This, in a nutshell, is the main argument for the proposed approach.

Second, analogies between the lack of credibility of debt limits in the original Stability and Growth Pact (SGP) and the debt limits as proposed here ignore the fundamentally different nature of these 
limits. In the context of the SGP, the limits were supposed to bind sovereign nations-a tall order, particularly with regard to powerful countries such as Germany and France, which in 2003 colluded to prevent the enforcement of the rules. Writing the charter of an official lender in a way that denies a country that has broken a debt ceiling finance is not the same-and is much more credible-as prohibiting that country from breaking the ceiling. Furthermore, the chance that euro area countries would collude to change the ESM rules is much lower. In particular, unlike the violation of the SGP limits, there is no sense that countries like Germany and France might benefit tomorrow by accepting a breach of the rule by another country today.

What about fears that debt/GDP numbers could be manipulated ${ }^{39}$ While this can never be ruled out, it is arguably less of an issue in the EU today than before, or internationally. Debt/GDP numbers are already enshrined in the fiscal framework and are closely monitored by the European Commission. One of the lessons of the euro debt crisis was to award Eurostat more powers to monitor countries' debt statistics and to close loopholes as they emerge (e.g., by defining the treatment of financial derivatives or of the liabilities of government-sponsored bad banks). Therefore, the risks of implicit debt are within the scope of the monitoring process in the EU at various levels. In addition to Eurostat, the European Systemic Risk Board and the Single Supervisory Mechanisms have a mandate to monitor contingent liabilities in the private and financial sectors. Also, as noted above, while a European Sovereign Debt Restructuring Regime will not by itself solve the private sector's debt problems, it may well ameliorate them; markets will be more likely to "price" sovereign default risks regardless of whether these originate from sovereign debt or from socialized private debt. This should give incentives to sovereigns to worry more about credit booms that could give rise to quasi-fiscal liabilities.

This leaves one potentially serious source of unintended consequences: the possibility that focusing all attention on just one number could invite misbehavior along other dimensions that carry no weight under the rules. However, there are ways to address this problem. In particular, greater use of short-term debt could be penalized by imposing the rule that in the event of a debt restructuring, haircuts on short-term debt will be higher than on longer maturities. At debt levels below 60 percent (where ESM lending is not conditional on fiscal adjustment and restructurings are excluded), the existing SGP criteria may need to be supplemented by a limit on the ratio of short- to long-term debt.

The long-run regime-governing debt restructurings in the euro area would be defined through the lending policies of the ESM, in the following manner:

1. Below 60 percent debt, access to the ESM is almost unconditional, in the sense that the ESM would not require fiscal adjustment or debt restructuring, except for a limit on short-term debt. Other types of conditionality may still apply, particularly in banking crises.

\footnotetext{
${ }^{39}$ In defining public debt one crucial distinction is between gross and net debt (see, e.g., Panizza and Presbitero 2013): Net government debt is normally obtained by subtracting the financial assets held by the government from gross debt. Differences between gross and net debt can be very large. At the end of 2012, average gross debt in countries that belong to the Organization for Economic Cooperation and Development was close to 110 percent of the group's GDP, but net debt was almost 40 percentage points lower than gross debt. Large differences between net and gross debt are sometimes due to the fact that the government holds a large fraction of its own debt. For instance, part of the U.S. government debt is held in the U.S. Social Security Trust Fund. Therefore, U.S. statistical sources often mention a measure of debt ("debt held by the public") that nets out these cross-holdings, and it is thus similar to a concept of net debt. In other cases, large difference between gross and net debt arise from the accumulation of international reserves or the presence of sovereign wealth funds. Calculating net debt requires a precise evaluation of government's assets and liabilities. This is a difficult exercise. Even netting cross-holdings of public sector bonds by separate public entities, and between national and subnational governments is not a simple exercise. Netting out cross-holdings of government assets also requires adjusting debt ratios for the liabilities associated with these cross-holdings. As a consequence, each country has its own definition of net debt which makes the statistic useless for cross country comparison. The EU defines government debt as used in the Maastricht criteria as gross debt and mandates Eurostat is to ensure a homogenous application of the definition across countries.
} 
2. Between 60 percent and an upper threshold, access to the ESM is conditional on and fiscal adjustment and structural conditionality. Debt restructuring would not be expected unless a debt sustainability analysis suggested that it is needed. In case of restructuring, debt of short maturities would be subject to a heavier haircut.

3. Above the upper threshold, access to ESM support is only be possible with an ESM-sanctioned debt restructuring program. The minimal extent of restructuring should be such that the countries debt level falls below the upper threshold with a safety margin.

Setting the Upper Threshold. In deciding where to set the higher threshold, there needs to be a balance between allowing flexibility and limiting overborrowing (see box 3). Countries that appear fiscally sound may experience sudden and large surges in debt levels during crises. Sudden debt jumps are most often the consequence of the eruption of a banking crisis, a natural disaster, or a war. Contingent debt from the financial system was the cause of the spectacular increase in debt levels (e.g., in Iceland or Ireland). In the future architecture of the euro area, such increases in debt due to banking liabilities should be mitigated by a common regime for bank restructuring and resolution.

The function of the threshold is to bind the hands of the euro area to share the burden with creditors in high-debt cases. A very low threshold is not desirable since it might trigger restructurings even in cases of temporary shocks. But a very high threshold would imply that the adjustment burden falls only on the shoulders of debtor countries (and possibly those of official lenders, if their loans are not repaid). For the financial architecture of the euro area, a very high threshold would imply that that the restructuring regime remains irrelevant. The present situation would persist even in the long run. Bail-ins would remain unlikely and unpredictable.

Of particular importance, the upper threshold would not necessarily act as an automatic restructuring trigger, nor as universal debt ceiling. It might be possible for a country to carry debt above the threshold if it could retain market confidence. But even if markets are willing to provide the finance, this does not necessarily mean that it is optimal to carry very high debt.

There are cases of countries with very high debt levels (above 100 or even 200 percent of GDP) that do not seem to be in danger of losing market access. But these are likely special cases where national savers and financial intermediaries are prepared to sustain these debt levels. ${ }^{40}$ In the euro area, the zone of vulnerability now seems to be much lower, or else Italy would not be considered a problem. Furthermore, given the demographics and relatively low potential growth prospects of advanced countries, it seems hard to argue that very high debt levels are optimal from a growth perspective (let alone from the intergenerational distribution perspective).

Fixing the upper debt ceiling will require further research, but a number that is about 1.5 times the lower ceiling seems reasonable.

Rules for Restructuring. Two rules would govern the amount and form of restructuring: (1) The minimum amount of restructuring should bring the debt level below the upper threshold; and (2) shorter maturity debt would receive a heavier haircut. Guidelines for the equitable treatment of various creditor classes would also apply, as described in the context of the SDAF proposed for the IMF.

The Policy Framework "Ties the Hands" of the ESM (and the Troika), since they no longer exercise

${ }^{40}$ For an analysis of the Japanese case, see Hoshi and Ito (2013). 


\section{Box 3. Episodes of Surges in Public Debt from 60 Percent}

While the lower threshold of 60 percent is generally accepted in the European Union, the upper threshold will be more contentious. After all, at present most EU members, as well as most other advanced economies, have debt levels of about 90 to 100 percent. Are they all to be considered "restructuring cases"?

First, it is important to stress again that the policies proposed in this section are for the long run (i.e., in a situation when the legacy of this crisis has been dealt with; see below). Second, we can ask how many episodes there have been where debt levels increased from below 60 percent to 90 percent, and how may years this process has taken in the past. Table 2 uses historical gross debt data from the IMF from 1880 to 2010 . We identify a total of 20 events in 15 countries, four of them in the euro area. Most episodes of surges in debt from 60 (or below) to 90 (or above) did play out over several years. On average, such an increase in debt took almost 6.5 years.

\section{Table 2. Episodes of Surges in Debt/GDP from 60 Percent to 90 Percent}

\begin{tabular}{|lcrccc|}
\hline & Start & End & Start & End & Years \\
Argentina & 36.2 & 90.6 & 1887 & 1891 & 5 \\
Argentina & 57.7 & 100.7 & 1927 & 1931 & 5 \\
Australia & 59.7 & 98.2 & 1927 & 1932 & 6 \\
Canada & 53.2 & 102.3 & 1929 & 1932 & 4 \\
Canada & 58.4 & 90.2 & 1982 & 1992 & 10 \\
Chile & 47.6 & 108.3 & 1971 & 1975 & 4 \\
Chile & 34.0 & 117.5 & 1982 & 1984 & 3 \\
Greece & 48.2 & 120.0 & 1886 & 1888 & 3 \\
Greece & 60.0 & 100.5 & 1989 & 1992 & 5 \\
Iceland & 29.1 & 92.8 & 2007 & 2010 & 4 \\
Indonesia & 26.4 & 95.9 & 1997 & 1999 & 3 \\
Ireland & 59.8 & 93.2 & 1981 & 1988 & 8 \\
Ireland & 44.3 & 92.2 & 2008 & 2010 & 3 \\
Italy & 58.5 & 90.8 & 1981 & 1988 & 8 \\
Japan & 57.2 & 95.9 & 1981 & 1996 & 15 \\
Malaysia & 52.7 & 106.3 & 1981 & 1986 & 5 \\
Portugal & 57.5 & 93.3 & 2004 & 2010 & 6 \\
Singapore & 59.7 & 94.8 & 1981 & 2001 & 19 \\
United States & 57.1 & 98.6 & 2002 & 2010 & 8 \\
Uruguay & 34.6 & 99.9 & 1982 & 1984 & 3 \\
Average & $\mathbf{4 9 . 6}$ & 99.1 & & & $\mathbf{6 , 4}$ \\
\hline
\end{tabular}

Note: Advanced or emerging market economies, 1880-2010.

Source: IMF.

We also conducted a similar exercise in which we identified episodes during which debt levels increased by 30 percent in one or two years irrespective of the starting level of debt. As expected, such extreme episodes tend to be associated with severe economic dislocations like those in the 1920s and 1930s, or with twin or triple crises. Overall, however, such debt jumps occurred at initial debt levels above 60 percent. The average starting level of all episodes was 84 percent, and the median was 70 percent.

Overall, the experience of advanced and emerging market economies of the last 130 years suggests that an upper threshold of debt/GDP between 90 and 100 percent would be enough to provide an adequate buffer during which adjustment can take place without markets having to worry about debt restructuring. 
discretion in times of distress. The advantage of such a framework is that it provides strong ex-ante incentives to discipline fiscal policies while at the same time narrowing the space within which restructurings and official interventions are possible.

To be effective in the sense of creating a genuine commitment device, the ESDRR would need to rule out access to IMF resources as a way of circumventing ESM access and restructurings in high debt cases. An easy way of achieving this would be to pool euro area membership at the IMF.

By construction, the ESDRR would be binding for countries of the euro area (since they are members of the ESM treaty). It may be possible to find ways for other EU member countries to join this regime voluntarily.

It is worth reiterating that this type of restructuring regime could not be implemented immediately. While it would constitute a stabilizing and disciplining mechanism in the long run, it would be highly destabilizing if implemented while debt levels are still very elevated. The section on dealing with legacy debt addresses the problem of transition to the long-run equilibrium and discusses various options on this path.

\section{Dealing with Holdouts in the Euro Area}

To immunize restructuring against holdouts, the 2012 Treaty Establishing the European Stability Mechanism would be amended as follows:

\section{ARTICLE__: Immunity from judicial process}

The assets and revenue streams of an ESM Member receiving stability support under this Treaty which are held in, originate from, or pass through the jurisdiction of an ESM Member shall not be subject to any form of attachment, garnishment, execution, injunctive relief, or similar forms of judicial process, in connection with a claim based on or arising out of a debt instrument that was eligible to participate in a restructuring of the debt of the beneficiary ESM Member after the effective date of this Treaty.

The immunities provided in the preceding paragraph shall automatically expire when all amounts due to the ESM from the beneficiary ESM Member have been repaid in full.

An amendment of the ESM treaty for this purpose would become effective within the jurisdiction of each of the euro area countries. The potency of the measure would obviously be enhanced if other EU members, particularly the United Kingdom, were to enact comparable immunities in their domestic law. A country such as the United Kingdom might for selfish reasons wish to incorporate such immunities into its own law; failure to do so could drive financial transactions away from London.

The justification for such an amendment of the ESM treaty from the perspective of the ESM and its members is self-evident and compelling. ESM member states will be lending taxpayer resources into a recipient country. If a restructuring of private sector claims is deemed essential to restore that country to a sustainable position, the members funding that bailout should not wish to see the assets and revenue streams of the recipient sovereign being seized by creditors that elect not to participate in the restructuring. Every $€ 1$ that is so seized and applied toward the immediate repayment of such a claim will logically require a corresponding $€ 1$ increase in the amount of ESM bailout assistance. ESM members have a legitimate interest in minimizing such transfers.

The foregoing is also consistent with the goal expressed in the preamble of the ESM that its funding to a distressed euro area member nation will receive priority over payments owed to private creditors. To the extent that ESM funds can be seized by private creditors that have refused to participate in the restructuring, those private creditors have effectively reversed the priority order (after all, they are getting paid and exiting, while the ESM 
is left holding the bag). ${ }^{41}$ The modification that we propose will help ensure that the ESM funding receives its promised priority.

Two precedents for this sort of mechanism are described in box 4 .

An amendment of the ESM treaty along the lines suggested above would, together with the other measures already taken within the euro area, substantially replicate the key features of most corporate insolvency regimes. Supermajority creditor control of a debt workout would occur by requiring the agreement of 75 percent of bondholders as a condition for ESM endorsement-defined across all bonds, in line with the aggregate threshold envisaged in the collective action clauses of all euro area sovereign bonds issued after January 1, 2013.

\section{Box 4. Precedents for Treaty-Based Mechanisms to Immunize Certain Payment Streams}

The first precedent is relatively recent and directly on point. In May 2003, following the coalition invasion of Iraq to oust Saddam Hussein, the United Nations Security Council (UNSC) adopted Resolution 1483 (May 22, 2003). ${ }^{42}$ Among other things, that resolution encouraged the new government in Iraq to restructure the roughly $\$ 140$ billion debt stock that Saddam had accumulated during his tenure. In the context of "the desirability of prompt completion of the restructuring of Iraq's debt," the resolution immunized all the petroleum assets of Iraq against "any form of attachment, garnishment, or execution," and clothed the proceeds of Iraqi oil sales (along with the bank account into which the proceeds of all such oil sales were to be directed) with privileges and immunities identical to those enjoyed by the United Nations itself.

Resolution 1483 was enacted pursuant to Chapter VII of the Charter of the United Nations. It was therefore binding on all members of the organization, and the resolution instructs each member state to "take any steps that may be necessary under their respective domestic legal systems to assure this protection" of Iraqi oil and financial assets. These UNSC-mandated immunities were periodically renewed and eventually expired on June $30,2011 .{ }^{43}$ In Europe, the immunities for Iraqi assets were implemented through EU Regulation 1210/2003 (July 7, 2003) and amended from time to time thereafter in response to UNSC resolutions. ${ }^{44}$

It worked. In late 2004, Iraq negotiated an 80 percent nominal write-off of its debt owed to Paris Club countries and a long-term restructuring of the balance of the claims. This translated into an 89.75 percent reduction in the net present value of those claims. That same net-present-value haircut was then offered to the holders of roughly $\$ 21$ billion of Saddam-era debt owed to private sector creditors, and virtually all those holders accepted it. The UNSC-mandated immunization of Iraqi assets undoubtedly helped to dampen any hope that a better recovery could be achieved at the sharp end of a litigation.

\footnotetext{
${ }^{41}$ The Austrian Ministry of Finance has a question-and-answer discussion regarding the ESM on its Web site. Contained in the Q\&A are a couple of questions and answers that help illustrate the point made in the text. On page 14, the question asked is: "Are only speculators going to be rescued?" In responding no, the document explains that "if [the] ability [to repay the ESM funding] is not already shown at the outset, then initially, financial investors will have to waive receivables in the course of debt adjustment proceedings before any aid funding can flow." On page 15, the question is "Has there been an infringement of Article 125 TFEU-the "no bailout" clause?" In responding no, the document explains that "where repayment is at risk, the restructuring clause for private investors will be triggered, because the ESM has priority over private creditors." See BMF Ministry of Finance, Q\&A European Stability Mechanism, http://english.bmf.gv.at/Allgemeines/FlashContent/ QAEuropeanStability_963/Q_A_European_Stability_Mechanism_(ESM).pdf.

${ }^{42}$ See United Nations, Security Council Resolution 1483, http://www.un.org/ga/search/view_doc.asp?symbol=S/RES/1483\%282003\%29.

${ }^{43}$ See United Nations, Security Council Resolution 1956, http://www.un.org/ga/search/view doc.asp?symbol=S/RES/1956\%282010\%29.

${ }^{44}$ See http://eur-lex.europa.eu/LexUriServ/LexUriServ.do?uri=OJ:L:2003:169:0006:0023:En:PDF.
} 
The second precedent is from a half century ago, but is relevant in that it shows how a treaty regime can facilitate a restructuring by constraining the enforcement rights of certain problematic debt claims.

In the period between 1924 and 1930, a number of German companies issued state-backed bonds in U.S. markets. Subsequently, before World War II, many of these bonds were reacquired by the issuers for retirement. These bonds, once reacquired, no longer represented valid obligations. However, because of the war, many of these reacquired bonds did not get canceled (the trustees or paying agents being generally located in New York). Instead, the uncanceled bonds were held in bank vaults in Germany. In 1945, at the end of the war, a large portion of these uncanceled bonds fell into the hands of the Soviet forces and were subsequently returned to circulation. When West Germany later sought to negotiate payments on its portion of the German defaulted debt from the prewar period, the question was how to distinguish between the authentic outstanding bonds and the ones that had been looted in $1945 .{ }^{45}$

To solve the problem, the United States and West Germany entered into a treaty on April 1, 1953, that decreed that the bonds in question would not be enforceable unless they had been first validated by a joint U.S.-German validation board. ${ }^{46}$ Further, the U.S. Securities and Exchange Commission issued a ruling that U.S. brokers and dealers were prohibited from trading in bonds that had not been validated. ${ }^{47}$ For over a half century now, this treaty mechanism has held up remarkably well in protecting against the claims on unvalidated bonds.

Although there would be no "automatic stay" preventing the initiation of creditor lawsuits against the sovereign debtor, the amendment to the Treaty Establishing the European Stability Mechanism proposed above would effectively shield the debtor country's euro-area-based assets from compulsory seizure by holdout creditors.

\section{Dealing with the debt overhang from the present crisis in the Euro area}

At mentioned above the provisions of the ESDRR - in particular, the binding debt thresholdsare not designed as a solution for the present debt crisis. In the short run, this option could not be activated since it would trigger immediate instability. In fact, it would serve a stabilizing function only if all participating countries start out with a debt level well below the upper threshold.
At the present juncture, the base case of transiting into a more stable long run in the euro area seems to rely primarily on improving the incentives and control mechanisms (six-pack, two-pack, European semester, and other torture instruments). The status quo does not provide for debt restructuring (beyond Greece) and does not foresee any mutualization of debt. It relies on the Outright Monetary Transactions (OMT) of the ECB, and beyond that it is based on the hope that the adjustment process and the structural reforms that debtor countries are undergoing will eventually bring rewards in terms of higher growth. The present strategy of dealing with the legacy debt is risky since it requires an extremely long and unilateral adjustment process on the side of the high-debt countries. It could easily derail for a number of reasons-for example, if growth fails to pick up for a few more years, if the credibility of the OMT fails or if the political will to drive reform is exhausted.

\footnotetext{
${ }^{45}$ For a fuller description of the background, see Abrey v. Reusch, 153 F. Supp. 337 (S.D.N.Y. 1957); and Mortimer Off Shore Services Ltd v. Federal Republic of Germany 615 F. 3d 97 (2d Cir. 2009).

${ }^{46}$ Certain Matters Arising from the Validation of German Dollar Bonds, U.S.-F.R.G., April 1, 1953, 4 U.S.T. 886, T.I.A.S. No. 2794 (entered into force September 16, 1953).

${ }^{47}$ Rule X-1502-3, Adopted Under the Securities and Exchange Act of 1934.
} 
There are, however, alternative options for dealing with the legacy debt problem. The first option is a minimal one, while the other requires a grand bargain between euro area countries.

\section{Restructure as Needed If Above the Upper} Threshold. This option assumes that further restructuring of sovereign legacy debt (in particular, if there is no further debt mutualization) might be inevitable in some countries. It therefore attempts to provide minimal conditions for containing the cost of such a restructuring. In particular, a minor amendment of the EMS treaty would provide restructuring countries with immunity from judicial process (as described above). Indeed, this immunity could arguably be implemented through a decision of the ESM Board of Directors, without any amendment to the treaty. ${ }^{48}$

In addition, any ESM-sanctioned debt-restructuring programs as a condition of financial support could be limited to countries with debt above the long-run upper threshold. The result would be to limit the range within which debt restructurings can be expected. While this option would make debt restructuring easier by making life more difficult for holdouts, it would do little to make restructuring more likely. The dominant incentives for debtor and creditors countries in the euro area would still be to procrastinate and gamble for resurrection, at least until an effective and durable firewall for other countries and for banking systems is in place.

Debt Redemption Pact. One way of crossing the bridge between the short-run debt overhang and a long-run restructuring regime is a European Debt Redemption Pact, as proposed by the German Council of Economic Experts (2011, 2012). This proposal entails a temporary pooling of sovereign debt above 60 percent (of nonprogram countries) and a gradual redemption over a period of 25 years. ${ }^{49}$ It would take countries about 5 years to gradually build up the common fund, which would at peak amount to about $€ 2.3$ trillion (the largest contributors would be Italy, Germany and France). With reasonable assumptions about growth, interest rates and primary surpluses, countries would be able to redeem their respective debts over the following 20 years. The "own" debt level would be down to 60 percent after five years; therefore, in principle, the ESDRR regime could become binding after that. This option avoids restructuring legacy debt, but it also requires significant political will and a long time commitment from the major euro area countries. Part of the deal would have to be a substantial strengthening of fiscal controls (e.g., by agreeing on a specific tax that would automatically increase in case the country falls short of the committed reform path). Also, there would have to be institutional mechanisms to ensure that mutualizing legacy debt would not reoccur. It would be a grand deal to secure the transition to a permanent sovereign debt restructuring regime that effectively harnesses market discipline.

\section{Summary of Proposals}

The summary table below gives an overview and comparison of our different proposals to organize orderly sovereign bankruptcy. The table is orga-

\footnotetext{
${ }^{48}$ According to the preamble of the ESM treaty, ESM funding is to carry preferred creditor status. At the same time, the treaty lacks a mechanism that implements that preferred creditor status. Article 5(7)(n), however, gives the Board of Directors the power to take "any other necessary decision not explicitly provided for by this Treaty."

${ }^{49}$ The focus of this section is to discuss transitional arrangements that would the euro zone to get from here the status quo (debt above thresholds and no restructuring regime) to there the proposed long run regime (debt below thresholds and a credible restructuring regime). There are other proposals with involving partial mutualization that are were designed as permanent features of the euro zone rather than transitory arrangements. E.g., these include the blue bond proposal by von Weizsäcker and Delpla (2010), which can be viewed as an alternative restructuring regime that excludes restructurings below 60 percent debt level (the amount of mutually issued blue bonds); Hellwig and Philippon (2011) propose mutualizing short-term debt, only in order to solve the problem of bond runs. Finally, the European Safe Bonds proposal by Brunnermeier et al. (2011) provides a solution to the safe asset problem, without mutualization, As an element of the European financial architecture, it would be consistent with the proposals made in this report, but it does not fix a debt reduction path. The proposal was not aimed at and as such does not describing a transition path to a restructuring regime with debt thresholds. Nevertheless, it might be a complement to a debt redemption pact, i.e., a permanent solution to providing a safe asset.
} 
nized in an ascending manner: moving to the right means applying stronger medicine, and deploying more political capital, but also moving considerably closer to solving the various incentive problems that mar sovereign debt markets.

At the one end of the spectrum is the status quo, which we argue should be reformed urgently because it provides poor incentives both ex ante and ex post. The success of holdouts on Argentina and Greece gives a boost to the business model of distressed debt funds specialized in litigation. They play a redistribution game, benefiting at the cost other private and official creditors, but by the same token making restructuring more difficult and delayed.

The minimum reform at the international level would therefore aim at preventing holdouts by adopting stronger collective action clauses that operate across all new debt contracts, giving a supermajority among all bondholders the right to restructure against the will of a minority (in the aggregate, and regardless of the votes of individual bond series), as long as the restructuring leads to bondholders identical payment terms for all bondholders. This would constitute a significant improvement over the status quo. But the strength of this instrument-even for the narrow purpose of preventing holdouts-would depend on the degree and speed of adoption of strong aggregation clauses in international debt contracts.

An alternative-and possibly complementaryapproach that would "defang" holdouts immediately would require changes in laws or regulations in the major financial centers in order to immunize payments and clearing systems against attempts to attach payments. This would imply, in particular, that holdouts would find it harder to interfere with the debt service payments of debtors to creditors that have agreed to a sovereign debt restructuring. It is still a minimal proposal, however, because it does not address poor incentives in the run-up to a restructuring.
The next proposal does address both ex-ante and ex-post distortions through a new sovereign debt adjustment facility, the SDAF of the IMF. Countries would have access to the SDAF (and only access to the SDAF, among IMF facilities) in a situation where debt sustainability is no longer assured without substantial debt relief. The SDAF would thus establish a commitment device that would preclude the Fund from financing countries with doubtful debt sustainability. A minor amendment of the IMFs Articles of Agreement could provide instant and global protection of payments on restructured debt holders that had participated in an SDAF-sponsored restructuring. Because access to the SDAF would depend on ex-ante criteriaas well as, of course, a debtor country's requestthis proposal would have a significant impact on ex-ante incentives, making it more likely that unsustainable debt situations would be recognized in a timely way, and that debt restructurings would restore sustainability.

The most far-reaching proposal in this report is the creation of a European Sovereign Debt Restructuring Regime. As discussed above, the euro area has both the largest need and the best chances to implement such as comprehensive solution. We propose implementing the regime through an amendment of the ESM treaty that defines conditions under which the ESM is allowed to lend only if the member country also restructures its debt, and that gives guidelines as to the minimal amount of restructuring. The treaty change would also make the assets and payments of euro area member that have undertaken an ESM-sanctioned restructuring immune from attachment by holdouts. The restructuring regime would tie into the European fiscal framework by using the 60 percent debt level as a threshold for conditioning official crisis lending. At debt levels below 60 percent, ESM lending would be largely unconditional; but at 60 percent plus $x$ (an upper threshold), ESM lending would be conditional on debt restructuring. The effect would be to limit the range within which the official sector can gamble for resurrection and create moral hazard for debtors and private creditors, 
while at the same time providing enough flexibility to accommodate large economic shocks. To be effective in credibly binding the hands of the ESM, access to IMF lending would have to be ruled out as a way of circumventing ESM conditionality (e.g., by pooling euro area membership at the Fund). By construction, the ESDRR would be binding for the countries of the euro area (since they are members of the ESM treaty); however, other EU member countries might be able to join voluntarily.
The ESDRR could obviously not be implemented immediately because it would be highly disruptive during the current ongoing crisis. But it would be a crucial stabilizing and disciplining mechanism in the long-run European architecture. In the short run, the challenge remains to design mechanisms that bring down debt levels quickly and smoothly while at the same time not compromising incentives for the long run. 


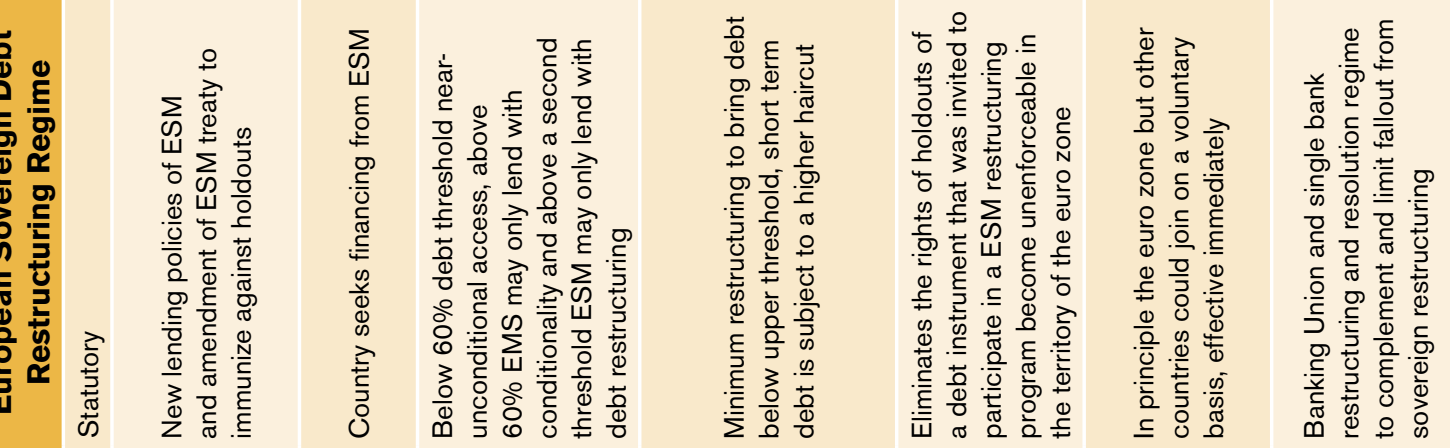

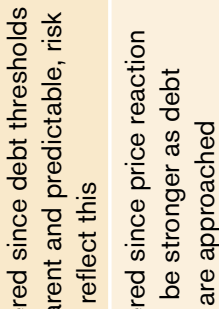

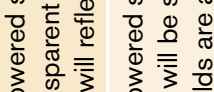

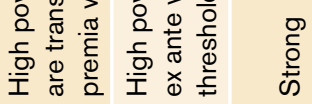

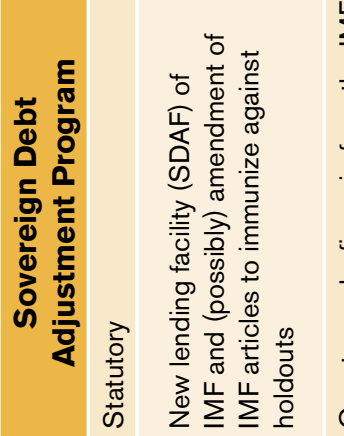

些证

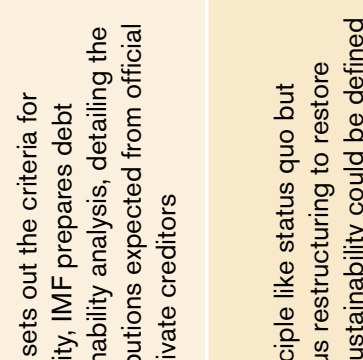

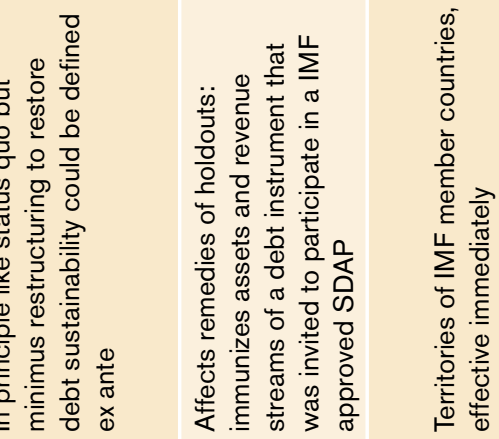

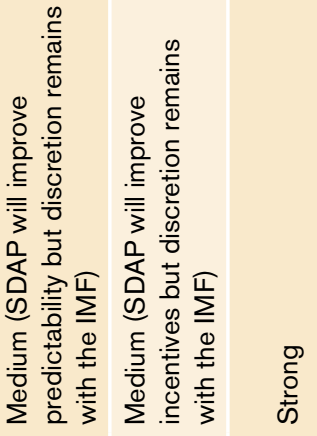

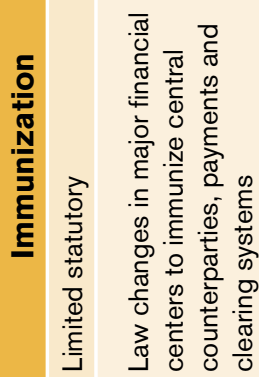

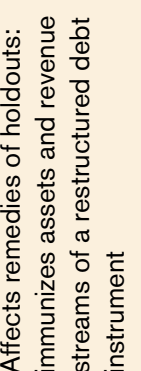

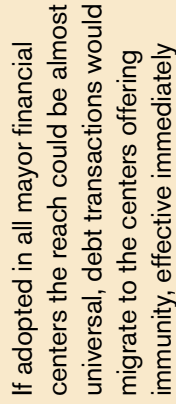

$\frac{0}{0}$
$\frac{0}{2}$
$\frac{0}{20}$
$\frac{\pi}{20}$

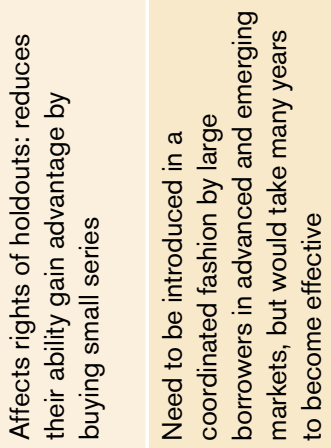

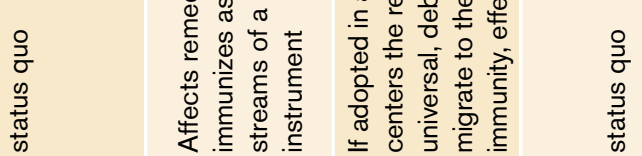

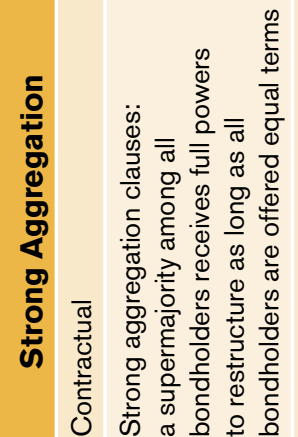



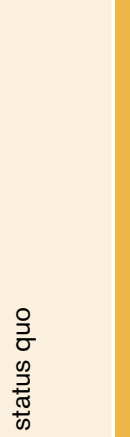


Acharya, Viral, and Raghuram Rajan. 2013. "Sovereign Debt, Government Myopia and the Financial Sector." Review of Financial Studies. Forthcoming.

Aguiar, Mark, and Manuel Amador. 2013. "Sovereign Debt." In Handbook of International Economics 4 , forthcoming.

Allen, Franklin, Stephen Morris, and Hyun Song Shin, 2006. "Beauty Contests and Iterated Expectations in Asset Markets." Review of Financial Studies (Society for Financial Studies) 19 (3): 719-52.

Becker, Torbjörn, Anthony J. Richards, and Yunyong Thaicharoen. 2003. "Bond Restructuring and Moral Hazard: Are Collective Action Clauses Costly?" Journal of International Economics (Elsevier) 61 (1, October): 127-161.

Bi, Ran, Marcos Chamon, and Jeromin Zettelmeyer. 2011. "The Problem That Wasn't: Coordination Failures in Sovereign Debt Restructurings.” IMF Working Paper 11/265. Washington: International Monetary Fund.

Bogdandy, Armin, and Matthias Goldmann. 2012. "Sovereign Debt Restructurings as Exercises of International Public Authority: Towards a Decentralized Sovereign Insolvency Law." Manuscript. http://ssrn.com/abstract=2089480 or http://dx.doi.org/10.2139/ssrn.2089480.

Bolton, Patrick, and Olivier Jeanne. 2007. "Structuring and Restructuring Sovereign Debt: The Role of a Bankruptcy Regime." Journal of Political Economy (University of Chicago Press) 115 (6): 901-24.

Borensztein, Eduardo, Marcos Chamon, Olivier Jeanne, Paolo Mauro, and Jeromin Zettelmeyer 2005. "Sovereign Debt Structure for Crisis Prevention." IMF Occasional Paper 237. Washington: International Monetary Fund.

Borensztein, Eduardo, and Ugo Panizza. 2009. "The Costs of Sovereign Default." IMF Staff Papers 56 (4): 683-741.
Bradley, Michael, and Mitu Gulati. 2012. "Collective Action Clauses for the Eurozone: An Empirical Analysis." Manuscript. http://ssrn.com/ abstract $=1948534$.

Broner, Fernando and Jaume Ventura. 2011. "Globalization and Risk Sharing." Review of Economic Studies 78: 49-82.

Broomfield, Elizabeth and Lee C. Bucheit. 2013. "Sovereign Debt Adjustment Program." Mimeo.

Brunnermeier, Markus K., Luis Garicano, Philip R. Lane, Marco Pagano, Ricardo Reis, Tano Santos, Stijn Van Nieuwerburgh, and Dimitri Vayanos. 2011. "European Safe Bonds: ESBies." Manuscript. Euro-nomics.com.

Brutti, Filippo, and Philip Sauré. 2013. "Repatriation of Debt in the Euro Crisis: Evidence for the Secondary Market Theory." Center for Institutions, Policy and Culture in the Development Process Working Paper No. 109. Zurich: University of Zurich.

Buchheit, Lee C., and Mitu Gulati. 2013. "Walking Back from Cyprus.” Working Paper. Durham, N.C.: Duke Law School Faculty Scholarship.

Buchheit, Lee C., Mitu Gulati, and Ignacio Tirado. 2012. "The Problem of Holdout Creditors in Eurozone Sovereign Debt Restructurings.” Manuscript. http://ssrn.com/abstract=2205704.

Bulow, Jeremy, and Kenneth Rogoff. 1989a. "A Constant Recontracting Model of Sovereign Debt." Journal of Political Economy 97 (1): 155-78.

-__. 1989b. "Sovereign Debt: Is to Forgive to Forget?" American Economic Review 79 (1): 43-50.

Calvo, Guillermo A. 2005. Emerging Capital Markets in Turmoil: Bad Luck or Bad Policy? Cambridge, Mass.: MIT Press.

Calvo, Guillermo A., Leonardo Leiderman, and Carmen M. Reinhart. 1993. "Capital Inflows and Real Exchange Rate Appreciation in Latin America: The Role of External Factors," IMF Staff Papers 40 (1): 108-51. 
Catão, Luis, Ana Fostel, and Sandeep Kapur. 2007. Persistent Gaps, Volatility Types, and Default Traps. IMF Working Paper 07/148. Washington: International Monetary Fund.

CIEPR (Committee on International Economic Policy and Reform). 2012. Banks and Cross-Border Capital Flows: Policy Challenges and Regulatory Responses. Washington: The Brookings Institution.

Cole, Harold L., and Patrick J. Kehoe. 1998. "Models of Sovereign Debt: Partial versus General Reputations." International Economic Review 39 (1): 55-70.

Cruces, Juan, and Christoph Trebesch. 2013. "Sovereign Defaults: The Price of Haircuts." American Economic Journal: Macroeconomics, forthcoming.

Das, Udaibir, Michael Papaioannou, and Christoph Trebesch. 2012. Sovereign Debt Restructurings 1950-2010: Literature Survey, Data and Stylized Facts. IMF Working Paper 12/203. Washington: International Monetary Fund.

Dell'Erba, Salvatore, Ricardo Hausmann, and Ugo Panizza. 2013. "Debt Levels, Debt Composition, and Sovereign Spreads in Emerging and Advanced Economies." Manuscript. Cambridge, Mass.: John F. Kennedy School of Government, Harvard University.

Dooley, Michael P. 2000. "Can Output Losses Following International Financial Crises Be Avoided?” NBER Working Paper 7531. Cambridge, Mass.: National Bureau of Economic Research.

Eaton, Jonathan, and Mark Gersovitz. 1981. "Debt with Potential Repudiation: Theoretical and Empirical Analysis." Review of Economic Studies 48 (2): 289-309.

EEAG (European Economic Advisory Group). 2011. "A New Crisis Mechanism for the Euro Area." In The EEAG Report on the European Economy 2: 71-96. Munich: CESifo.

Eichengreen, Barry, Ricardo Hausmann, and Ugo Panizza. 2005. "The Pain of Original Sin." In Other People's Money, edited by B. Eichengreen and R. Hausmann. Chicago: University of Chicago Press.
Eichengreen, Barry, Robert Feldman, Jeff Liebman, Jürgen von Hagen, and Charles Wyplosz. 2011. "Public Debts: Nuts, Bolts and Worries." Manuscript. Centre for Economic Policy Research and International Center for Monetary and Banking Studies, September.

Eichengreen, Barry, and Ashoka Mody. 2000. "Would Collective Action Clauses Raise Borrowing Costs? An Update and Additional Results." Policy Research Working Paper 2363. Washington: World Bank.

Eichengreen, Barry, and Richard Portes. 1995. Crisis? What Crisis? Orderly Workouts for Sovereign Debtors. London: Centre for Economic Policy Research.

Gelpern, Anna, and Mitu Gulati. 2006. "Public Symbol in Private Contract: A Case Study." Washington University Law Review 84: 16271715.

-_-. 2012. "CDS Zombies." European Business Organization Law Review 13 (3): 347-390.

Gianviti, François, Jürgen von Hagen, Anne O. Krueger, Jean Pisani-Ferry, and André Sapir. 2010. A European Mechanism for Sovereign Debt Crisis Resolution: A Proposal. Bruegel Blueprint. Brussels: Bruegel.

German Council of Economic Experts. 2011. "Chapter 3, Euro Area in Crisis." In Annual Report. Wiesbaden: German Council of Economic Experts. http://www.sachverstaendigenrat-wirtschaft.de/fileadmin/dateiablage/ Sonstiges/chapter three 2011.pdf.

- - . 2012. Special Report: After the Euro Area Summit-Time to Implement Long-term Solutions. Wiesbaden: German Council of Economic Experts.

González-Rozada, Martín, and Eduardo Levy Yeyati. 2008. "Global Factors and Emerging Market Spreads." Economic Journal (Royal Economic Society) 118 (533): 1917-36.

Grossman, Herschel I., and John B. Van Huyck. 1988. "Sovereign Debt as a Contingent Claim: Excusable Default, Repudiation, and Reputation." American Economic Review 78 (5): 1088-97.

Gulati, Mitu, and Robert E. Scott. 2012. The Three and a Half Minute Transaction: Boilerplate and 
the Limits of Contract Design. Chicago, Il: University of Chicago Press.

Hans-Werner, Sinn, and Timo Wollmershäuser. 2012. "Target Balances and the German Financial Account in Light of the European Balance-of-Payments Crisis." CESifo Working Paper Series 4051. Munich: CESifo Group.

Hatchondo, Juan Carlos, Leonardo Martinez, and Cesar Sosa Padilla. 2012. "Debt Dilution and Sovereign Default Risk." Working Paper 1008. Richmond, Va.: Federal Reserve Bank of Richmond.

Hausmann, Ricardo, and Ugo Panizza. 2003. “On the Determinants of Original Sin: An Empirical Investigation." Journal of International Money and Finance 22 (7): 957-90.

Hellwig, Christian, and Thomas Philippon. 2011. "Eurobills not Eurobonds." Manuscript, VOXEU.

Hoshi, Takeo, and Takatoshi Ito. 2012. "Defying Gravity: How Long Will Japanese Government Bond Prices Remain High?” NBER Working Papers 18287. Cambridge, Mass: National Bureau of Economic Research.

Hughes Hallett, Andrew J., and Juan Carlos Martinez Oliva. 2013. "The Importance of Trade and Capital Imbalances in the European Debt Crisis." Working Paper Series WP13-1. Washington: Peterson Institute for International Economics.

IMF (International Monetary Fund). 2006. "Cross-Country Experience with Restructuring of Sovereign Debt and Restoring Debt Sustainability." Manuscript. http://www.imf.org/ external/np/pp/eng/2006/082906.pdf.

_-_. 2013. "Sovereign Debt Restructuring: Recent Developments and Implications for the Fund's Legal and Policy Framework." Manuscript. http://www.imf.org/external/np/pp/ eng/2013/042613.pdf.

Inter-American Development Bank. 2006. Living with Debt. Cambridge, Mass.: Harvard University Press.

Jeanne, Olivier, and Jeromin Zettelmeyer. 2001. "International Bailouts, Moral Hazard and Conditionality." Economic Policy (CEPR, CES, and MSH) 16 (33, October): 407-432.
Jeanne, Olivier, and Jermoin Zettelmeyer. 2004. "The Mussa Theorem: and Other Results on IMF Induced Moral Hazard." IMF Working Paper No. 04/192. Washington: International Monetary Fund.

Lane, Philip R. 2012. "The European Sovereign Debt Crisis." Journal of Economic Perspectives 26 (3): 49-68.

Lane, Philip R., and Barbara Pels. 2012. "Current Account Imbalances in Europe." Institute for International Integration Studies Discussion Paper No. 397. Dublin: Institute for International Integration Studies.

Levy Yeyati, Eduardo, and Ugo Panizza. 2011. “The Elusive Costs of Sovereign Defaults.” Journal of Development Economics (Elsevier) 94 (1): 95-105.

McKinnon, Ronald I., and Huw Pill. 1996. "Credible Liberalizations and International Capital Flows: The 'Overborrowing Syndrome."' In Financial Deregulation and Integration in East Asia, NBER-EASE, Volume 5. Cambridge, Mass.: National Bureau of Economic Research.

Miller, Marcus, and Dania Thomas. 2013. "Eurozone Sovereign Debt Restructuring: Promising Legal Prospects?" Manuscript. University of Warwick.

Missale, Alessandro. 1999. Public Debt Management. Oxford: Oxford University Press.

Mitchener, Kris James, and Marc D. Weidenmier. 2005. "Super Sanctions and Sovereign Debt Repayment.” NBER Working Paper 11472. Cambridge, Mass.: National Bureau of Economic Research.

Mody, Ashoka. 2013. "Sovereign Debt and Its Restructuring Framework in the Euro Area." Bruegel Working Paper 2013/05. Brussels: Bruegel.

Panizza, Ugo. 2013. "Do We Need a Mechanism for Solving Sovereign Debt Crises? A RuleBased Discussion.” IHEID Working Paper 032013. Geneva: Economics Section, Graduate Institute of International Studies.

Panizza, Ugo, and Andrea F. Presbitero. 2012. "Public Debt and Economic Growth: Is There a Causal Effect?” POLIS Working Papers no. 198. Alessandria, Italy: Institute of Public Policy and Public Choice - POLIS. 
Panizza, Ugo, Federico Sturzenegger, and Jeromin Zettelmeyer. 2009. "The Economics and Law of Sovereign Debt and Default." Journal of Economic Literature (American Economic Association) 47, no. 3: 651-98.

Powell, Andrew. 2011. "Bipolar Debt Restructuring: Lessons from LAC.” Manuscript. Vox Lacea, February.

———. 2013. "Sovereign Debt Restructuring." Presentation delivered on June 6, 2013 at the Sixteenth Workshop on International Economics and Finance in Santo Domingo, Dominican Republic.

Powell, Andrew, Guido Sandleris, and PilarTavella. 2013. "Multiple Restructurings, Delays and Haircuts." Manuscript. Inter-American Development Bank.

Reinhart, Carmen, Kenneth Rogoff, and Miguel A. Savastano. 2003. "Debt Intolerance." Brookings Papers on Economic Activity 34 (1): 1-74.

Rogoff, Kenneth. 2003. "Emerging Market Debt. What Is the Problem?" Speech given at Sovereign Debt Restructuring Mechanism Conference, Washington, January 22. http://www. imf.org/external/np/speeches/2003/012203a. htm.

Rogoff, Kenneth, and Jeromin Zettelmeyer. 2002. "Bankruptcy Procedures for Sovereigns: A History of Ideas, 1976-2001." IMF Staff Papers 49 (3): 470-507.

Sachs, Jeffrey, and Daniel Cohen. 1982. LDC Borrowing with Default Risk. NBER Working Paper 925. Cambridge, Mass.: National Bureau of Economic Research.

Sandleris, Guido, 2008. "Sovereign Defaults: Information, Investment and Credit." Journal of International Economics (Elsevier) 76 (2): 267-75.

-_- 2012. The Costs of Sovereign Defaults: Theory and Empirical Evidence. Business School Working Paper 2012-02. Buenos Aires: Universidad Torcuato Di Tella.

Schumacher, Julian, Christoph Trebesch, and Henrik Enderlein. 2012. "Sovereign Defaults in Court: The Rise of Creditor Litigation 1976-2010." Manuscript. http://ssrn.com/abstract $=2189997$.
Shambaugh, Jay C. 2012. “The Euro's Three Crises." Brookings Papers on Economic Activity (Spring 2012): 157-231. Washington: The Brookings Institution.

Shleifer, Andrei. 2003. "Will the Sovereign Debt Market Survive?" American Economic Review, Papers and Proceedings 93 (2): 85-90.

Sturzenegger, Federico, and Jeromin Zettelmeyer. 2007. “Creditors' Losses versus Debt Relief: Results from a Decade of Sovereign Debt Crises." Journal of the European Economic Association 5 (2): 343-51.

Tavella, Pilar. 2013. "Delays and Haircuts." Master's thesis. Universidad De San Andres, Buenos Aires.

Tomz, Michael. 2007. Reputation and International Cooperation: Sovereign Debt across Three Centuries. Princeton, N.J.: Princeton University Press.

Tomz, Michael, and Mark Wright. 2013. "Empirical Research on Sovereign Debt and Default," Manuscript. University of California, Los Angeles.

Trebesch, Christoph. 2013. "Delays in Sovereign Debt Restructurings.” Manuscript. University of Munich.

Weder di Mauro, Beatrice, and Jeromin Zettelmeyer. 2010. "European Debt Restructuring Mechanism as a Tool for Crisis Prevention." Manuscript. Vox Eu, November 26.

Weidemaier, W. Mark C. Forthcoming. "Sovereign Immunity and Sovereign Debt." University of Illinois Law Review.

von Weizsäcker, Jakob, and Jacques Delpla. 2010. "The Blue Bond Proposal." Bruegel Policy Brief 2010/03. Brussels: Bruegel.

Wright, Mark. 2011. "Sovereign Debt Restructuring: Problems and Prospects." Manuscript. University of California, Los Angeles.

Zettelmeyer, Jeromin, and Beatrice Weder di Mauro. 2010. "Ein Wirksamer Europäischer Krisenmechanismus." Neue Zürcher Zeitung, December 15.

Zettelmeyer, Jeromin, Christoph Trebesch, and Mitu Gulati. 2013. "The Greek Debt Restructuring: An Autopsy." Economic Policy 28 (75): 513-563. 
The views expressed in this publication are those of the authors and should not be attributed to their affiliated organizations.

\section{BROOKINGS}

1775 Massachusetts Avenue, NW

Washington, DC 20036

202-797-6000

www.brookings.edu/global 